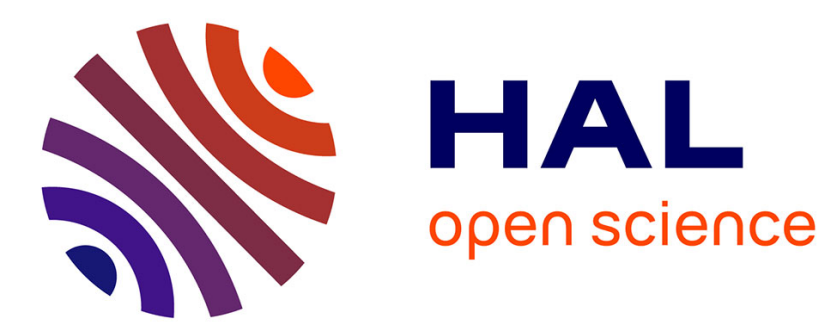

\title{
Better stuck together or free to go? Of the stability of cooperation when individuals have outside options
}

\author{
Alexia Gaudeul, Paolo Crosetto, Gerhard Riener
}

\section{To cite this version:}

Alexia Gaudeul, Paolo Crosetto, Gerhard Riener. Better stuck together or free to go? Of the stability of cooperation when individuals have outside options. Journal of Economic Psychology, 2017, 59 (April), pp.99-112. 10.1016/j.joep.2017.01.005 . hal-01461165

\section{HAL Id: hal-01461165 \\ https://hal.science/hal-01461165}

Submitted on 25 May 2020

HAL is a multi-disciplinary open access archive for the deposit and dissemination of scientific research documents, whether they are published or not. The documents may come from teaching and research institutions in France or abroad, or from public or private research centers.
L'archive ouverte pluridisciplinaire HAL, est destinée au dépôt et à la diffusion de documents scientifiques de niveau recherche, publiés ou non, émanant des établissements d'enseignement et de recherche français ou étrangers, des laboratoires publics ou privés. 


\title{
Better stuck together or free to go? Of the stability of cooperation when individuals have outside options. ${ }^{\text {th }}$
}

\author{
Alexia Gaudeul ${ }^{\mathrm{a}, *}$, Paolo Crosetto ${ }^{\mathrm{b}}$, Gerhard Riener $^{\mathrm{c}}$ \\ ${ }^{a}$ Chair of Microeconomics, Georg-August-Universität, Göttingen. \\ ${ }^{b}$ GAEL, INRA, CNRS, Grenoble INP, Univ. Grenoble-Alpes, 38000, Grenoble, France. \\ ${ }^{c}$ DICE, Heinrich-Heine-Universität, Düsseldorf.
}

\begin{abstract}
How do outside options affect cooperation? We examine the stability of cooperation and the reasons for exit in public projects with stochastic outcomes, imperfect monitoring and an exit option. We find that treatments with high barriers to exit generate higher welfare overall as they foster stability and prevent inefficient separation of pairs. There is excessive exit in treatments with low barriers to exit, driven in part by an overestimate of the likelihood that the peer will leave and a desire not to be left alone in the public project. We contrast long-term "strategic" and short-term "egoistic" drivers of exit and find that short-term cost-benefit considerations play a more important role in treatments with lower barriers to exit.
\end{abstract}

JEL Codes: C23, C92, H41

PsycINFO Classification code: 3020 Group \& Interpersonal Processes

Keywords: beliefs, cooperation, exit, outside option, public goods, stability

\footnotetext{
This research was funded by the Federal Program ProExzellenz of the Free State of Thuringia and by the Max Planck Institute of Economics. We thank audiences at conferences in Castellón, Cologne, Jena and Toulouse.

${ }^{*}$ Corresponding author

Email addresses: alexia.gaudeul@wiwi.uni-goett ingen.de (Alexia Gaudeul), paolo.crosetto@inra.fr (Paolo Crosetto), riener@dice.hhu.de (Gerhard Riener)
} 
We run an experimental study of the dynamics of cooperation in common projects with two participants. We allow exit from the common project and examine how this influences the behavior and the beliefs of the participants, and, as a consequence, the efficiency of their collaboration. The experiment we present here is designed to explore the dynamics of contribution and exit in contexts where participants have only imperfect information about the level of commitment of their peer to their common project.

In our experiment, pairs of subjects have to choose between joining either a private or a public project. After learning which project their peer joined, subjects must decide how much to contribute to their chosen project. The outcome of their chosen project depends on their own contribution and on the contribution of their peer (if they both chose to participate in the public project). Outcome is a stochastic (random) variable which can take only two values, high in case of success, low in case of failure. Higher contributions to a project increase the probability of success but cannot guarantee it. Even if both participants exert high effort, there is always some probability that the project will fail. If subjects had information about how much effort their partner exerted, they would be able to condition their behavior on the level of effort of their partner, rather than merely on the outcome of the common project. However, they do not have access to this information and therefore have to infer the level of contribution of the other participant from the success or failure of the common project. Participants have to judge, after a failure, whether they are better off staying together - if the failure was due to bad luck - or breaking off collaboration - if the failure was due to low effort by the other participant.

Five aspects of our experimental design are particularly important: 1) Subjects cannot monitor the contribution of others. There is imperfect monitoring because there is no way to directly infer contribution by the partner from the outcome of the joint project. 2) Exit is an individual decision. Defection to a private project by one agent does not imply the other agent has to exit the public project as well. 3) Exit is observable. After deciding what project to join, agents are informed of the joining decision of their peer. 4) Exit is a binary decision. Agents have to decide what project to participate in, they cannot choose to split their contributions between the public project and their private project. 5) Exit is reversible. Exit in one period can be followed by a return to the public project in the next period. This design means that our subjects always face the same range of options each period. Every period is formally comparable to every other in terms of the decisions to be taken. This simplifies the analysis of the game.

We run several treatments with different levels of barriers to exit. Results reveal a high level of inefficient dissolution of pairs when barriers to exit are low. However, lower barriers to exit do not influence the level of cooperation in public projects. We identify two drivers of exit: exit based on a cost-benefit analysis, which leads to permanent exit if working alone provides higher expected utility, and exit based on strategic considerations, where exit punishes failures in the pairing and occurs with the intent to come back later. We find that the cost-benefit drivers of exit are more important in treatments with low barriers to exit, while strategic considerations are the main drivers of exit in treatments with high barriers to exit. We conclude that lower barriers to exit lower the sense of collective efficacy of individuals in teams (Katz-Navon and Erez, 2005). They encourage individuals to focus more narrowly on their individual self-interest rather than invest in maintaining high levels of contributions over the long-term.

Motivation. Our experiment is motivated by the abundance of risky cooperative joint ventures in society and in the economy. Whenever two persons join to pursue a common project, be it raising children, establishing a business or writing a scientific article, joint effort increases the chances of success but there is always the possibility of free-riding, which can lead both participants to 
contribute very little. Both members of the pair have access to a variety of outside options; they are free to leave the pair and go work on their own. Moreover, success often does not depend only on effort, but also on exogenous factors. For example, success in innovative joint projects (research joint ventures, co-authorship) depends not only on effort but also on unpredictable events. This makes it difficult to distinguish, in case of failure, whether this was due to bad luck or to negligence.

Exit options and random outcomes are especially salient in the context of team work in innovative and rapidly changing environments, whereby the outcomes of one's effort is difficult to predict. Modern organization of collaborative work is such that team members may be located in different places and deal with different aspects of a project. This makes it difficult for them to monitor and judge the peer's commitment to their common project. A particularly relevant case is opensource software development, in which groups of developers work together remotely on common code bases, while retaining their freedom to move to other projects. Several different licenses exist, such as the GPL or the BSD. Those differ in the opportunities for developers to use code for their own purposes in commercial projects. The value of exit options thus depends on the license, which can affect user and developer interest and the direction of development (Lerner and Tirole, 2005; Stewart et al., 2006).

Another context that is of relevance to our experiment is that of the dynamics of marriage. Evolution of the legislation in many countries has made divorce easier, and this increased divorce rates (González and Viitanen, 2009). An objective appraisal of the welfare effect of such reforms is difficult (Amato and Keith, 1991; Chiappori et al., 2002). On the one hand, people are not forced anymore to maintain unwanted relationships. On the other hand, easier divorce can induce lower motivation to maintain a well-functioning relationship as alternatives are more readily available.

\section{Literature}

Relevant literature explores how exit options influence the likelihood and efficiency of collaboration, and how collaboration can be maintained in contexts where contributions by others are not directly observable.

The impact of exit options. While there exists a vast literature on public good provision and its dynamics, little attention has been devoted to the distinction between low contributions and the outright dissolution of a partnership. This distinction is akin to the difference between a dysfunctional marriage and one that ends in a divorce.

The small theoretical and empirical literature on exit focuses on how the ease of exit impacts contributions into a public project as well as its probability of survival. Some authors argue that it should be easy to exercise an exit option. Allowing exit may provide a way out from dysfunctional pairs and thus promote efficiency (MacLeod, 1993). The threat of exit may be necessary to enforce cooperation if participants can only imperfectly monitor each other, as it provides the only clear way to express dissatisfaction (Lin, 1990). Exit may be a way to signal dissatisfaction with the peer and thus rectify his or her attitude (Fujiwara-Greve and Yasuda, 2011). Allowing exit may also help to frame the collaboration as the product of the free will of both participants and thus promote intrinsic motivations for cooperation (Yamagishi, 1988). With exit options, the choice of staying in the pairing may also be a way to signal trust. This can promote cooperation because people are generally keen to uphold the trust of others (Bravo and Squazzoni, 2013). Finally, allowing exit may promote efficient self-selection: those who do not trust others self-select out, while cooperative types self-select in, thus promoting pairs that are stable and efficient (Orbell et al., 1984; Rand et al., 2011). Other authors have underlined the negative consequences of allowing exit. Giving outside options may reduce the interdependence between participants: the possibility of exit implies that a 
peer can easily escape punishment for low contributions (MacLeod, 1988; Putterman and Skillman, 1992; Dong and Dow, 1993). Allowing exit may also encourage peers to think of their own selfinterest ("could I do better outside?") rather than thinking in terms of the pair ("how can I make it work better?") (Tenbrunsel and Messick, 1999). Finally, making more severe sanctions available, such as exit, may lower the trust that participants have in each other (Mulder et al., 2006).

Experimental research on the benefits and drawbacks of outside options in collaborative environments is also quite sparse. We know that contributions in public good games decline over time (Neugebauer et al., 2009; Fischbacher and Gächter, 2010), but the standard implementation of the public good game does not allow outright leaving from a public project. We therefore know little about if, why and when peers decide to leave common projects. The standard implementation of the public good game can however be said to offer a continuous measure for exit: this is the part of one's endowment that one does not invest in the public good. The relative profitability of such "exit" is determined by the relation between the return obtained from the private and from the public goods. Research shows "a strong negative relationship between the marginal rate of substitution (between private and public goods) and the rate of contribution" (Palfrey and Prisbrey, 1996, p. 413). Low private opportunities thus increase public contributions.

Experiments that explicitly introduce an exit option mainly rely on binary implementations of the public good game: subjects play a prisoner's dilemma where in addition to the options to contribute or defect, they can also choose to exit. A strategy of out-for-tat, whereby not cooperating is punished by exit, obtains higher payoffs than tit-for-tat in some settings (Hayashi and Yamagishi, 1998). A few experiments implement the public good game with an exit option and continuous contributions, but they consider only the case where outcomes are deterministic. Keser and Montmarquette (2011) give the option between public and private good production and vary the value of the outside option. They find that providing an outside option increases investment levels in public projects. My and Chalvignac (2010) consider 5-player groups playing a linear public good game with fixed exit payoffs, and find that valuable outside options help maintain contribution levels over time.

Collaboration with imperfect monitoring of the action of others. Research about how random exogenous shocks affect collaboration in teams is limited. If success is not directly linked to effort and participants cannot monitor the contributions of others, then it is difficult to attribute failure to either low effort by others or bad luck. This is predicted to make cooperation more difficult (Van Dijk et al., 2004; Van Lange et al., 2013, pp. 131-132). Indeed, not being able to know for sure how much one's peer contributed reduces the scope of most of the contribution-enhancing mechanisms identified in the literature, such as the warm glow effect (Palfrey and Prisbrey, 1997), conditional cooperation (Keser and Winden, 2000; Fischbacher et al., 2001), conformity and reciprocity (Bardsley and Sausgruber, 2005), and it makes punishment less immediate and thus less effective (Ambrus and Greiner, 2012; Grechenig et al., 2010; Xiao and Kunreuther, 2012). Moreover, uncertainty as to the contribution of the peer gives a key role to beliefs, expectations, trust, and psychological aspects such as anxiety, guilt and inequality aversion. Individuals who are sensitive to such feelings may prefer to avoid joint projects even in the absence of free-riding.

A few experiments introduce stochastic (random) outcomes in public good games. For the prisoner's dilemma, cooperation is less frequent if outcomes are random, whether the peer's actions are observable (Bereby-Meyer and Roth, 2006), or not (Aoyagi and Fréchette, 2009). For public good games with continuous choice of contributions, Dickinson (1998) does not find a clear effect of uncertainty on contributions. Cason and Khan (1999) underline that imperfect information about the action of others is the main issue in such settings rather than uncertainty about the outcome of 
one's action. This is confirmed in Levati and Morone (2013) who find that neither uncertainty nor risk aversion lead to lower contributions when there is perfect monitoring of the action of others. There is no other experiment than ours in the current literature that combines stochastic outcomes in a public good game, imperfect monitoring of the action of others and an exit option. However, Wilson and $\mathrm{Wu}$ (2014) experimentally analyze a prisoner's dilemma combining exit option and stochastic outcomes in which the peer's decision is not observed. They find that subjects are more likely to exit in treatments with higher exit payoffs and that the average frequency of cooperation within pairings is higher in treatments with rather than without an exit option.

\section{The experiment}

Subjects played the main game which was followed by a questionnaire and some control tasks. Payoffs were disclosed and paid out only at the end of the session.

\subsection{The main game}

Each subject $i$ was randomly paired with another anonymous participant $j$ (the "peer") to form a pair $k$ and was asked to make a succession of decisions over several periods.

\section{Within-period timeline}

Figure 1 represents the within-period timeline in our experiment.

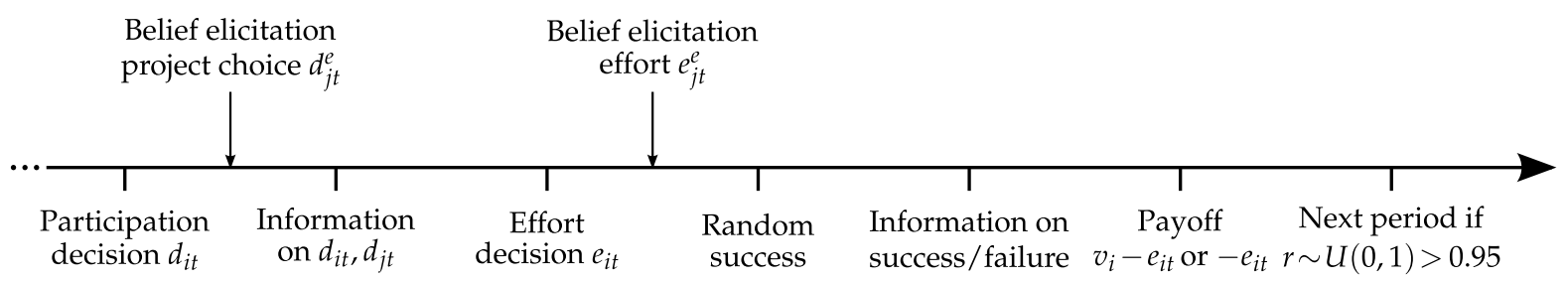

Figure 1: Within-period timeline

Subjects had to decide each period $t$ whether to participate to the public project $\left(d_{i t}=1\right)$ or to their own individual project $\left(d_{i t}=0\right)$. They were then asked to state their belief about the project choice of the peer in terms of the likelihood that the peer had stayed in the public project $\left(d_{j t}^{e} \in[0,1]\right)$. They then learned the participation decision of the peer, $d_{j t}$, and had to decide what level of effort to exert in their chosen project $\left(e_{i t} \in[0,10]\right)$. They were then asked to state their belief about the effort choice of the peer $\left(e_{j t}^{e} \in[0,10]\right)$. For consistency, this was elicited whether the peer was in the same project as themselves or not. Belief elicitation was incentivized using a linear scoring rule. ${ }^{1}$

Given their own effort and the effort of the peer, success in the chosen project was determined as follows:

- If subjects chose the public project, then their probability of success was $f\left(e_{i t}+d_{j t} \cdot e_{j t}\right)$ with function $f(z)=\sqrt{\frac{z}{22}}$ commonly known and presented as a printed-out table for all combinations of integers between 0 and 10. Subjects were also given an interactive payoff exploration tool, allowing them to compute success probabilities for non-integer levels of effort and were allowed to express effort with a precision up to the second decimal point.

\footnotetext{
${ }^{1}$ Risk-averse subjects can theoretically hedge their decisions in the main game by misreporting their beliefs, but a test of the empirical relevance of such hedging effects in the lab shows that "hedging confounds are not a major problem unless hedging opportunities are very prominent" (Blanco et al., 2010).
} 
- If they chose the individual project, then success occurred with probability $f_{l}\left(e_{i t}\right)$, with function $f_{l}\left(e_{i t}\right)$ depending on the treatment $l=\{0,1,2,3,4\}$ (see Section 1.4).

Subjects were then informed of the success or failure of their chosen project, but not of that of the project chosen by the peer if the peer chose to participate in his own individual project. They never learned the effort exerted by the peer. Subject $i$ obtained payoff $v_{i}$ if the project he was involved in was successful, 0 else. $v_{i}$ and $v_{j}$ were commonly known by both participants. Payoff for subject $i$ in period $t$ was thus $v_{i}-e_{i t}$ in case of success and $-e_{i t}$ in case of failure.

\section{Between-period timeline}

Subjects were told that the peer remained unchanged in the next period with a probability of 95\%. If the peer changed, they were informed of this and paired with a new peer for a number of periods. Subjects were told they will be assigned three peers in succession over the course of the experiment. We applied perfect stranger matching: subjects knew that they would not be matched twice with the same person over the course of the experiment, nor with anyone who was matched with someone they were previously matched with. We drew the number of periods in each matching beforehand according to the announced random process, so that in each session the first matching lasted 8 periods, the second 14 and the last 10, for a grand total of 32 repetitions of the game.

Success was determined as follows: For each of 32 periods $(t)$ and 16 pairs $(k)$, we independently drew a number $r_{k t}$ from a uniform distribution over the interval $[0,1]$. Success occurred for pair $k$ in period $t$ if $f\left(e_{i t}+d_{j t} \times e_{j t}\right)>r_{k t}$ if subject $i$ was in the public project, and if $f_{l}\left(e_{i t}\right)>r_{k t}$ if in the individual project. To control for possible effects of biased random draws in small samples, the same matrix $\left[r_{k t}\right]_{16 \times 32}$ was used for all sessions.

Participants were shown at the end of each period a history box, showing their past project and effort choices in the current pair, as well as whether their chosen project was a success or a failure. They also saw their own past project choices and those of the peer in the current pair. They were given no information about the effort of the peer, and information about success of the peer was given only if both participated in the public project.

\subsection{Control tasks, control questions and socio-demographic questionnaire}

At the end of the main part of the experiment, participants completed two unannounced, incentivized control tasks to assess their attitudes to risk, to strategic uncertainty, and their social value orientation. We used the Strategic Uncertainty and Risk Aversion tasks ( $s u$ and $r a$ ) of Heinemann et al. (2009) and a short, 6 -item version of the Social Value Orientation (svo) measure by Murphy et al. (2011). In addition to those incentivized controls, we collected the gender (female), age (age) and field of education (educ) of the participants. We also assessed their degree of trust in others following Gächter et al. (2004) (trust, high values indicate more trustful individuals). More details about the tasks and the questionnaire are given in Section B.2 of the Supplementary Material. ${ }^{2}$

\subsection{Payment}

A random period was drawn at the end of the experiment. Subject $i$ received 0 or $v_{i}$ depending on the success of the chosen project in that period, minus the effort $e_{i t}$ exerted in that period. In addition to this, subjects were paid for the accuracy of their elicited beliefs that period (linear

\footnotetext{
${ }^{2}$ For the impact of SVO and trust see Van Lange et al. (2013, pp. 132-133). Risk aversion may (Charness and Villeval, 2009) or may not (Kocher et al., 2015) lead subjects to invest more in order to reduce uncertainty. Strategic uncertainty aversion could lead subjects to avoid joint work. Women might be more attracted to cooperation (Kuhn and Villeval, 2014). Older people might be more pro-social (List, 2004). Economics students might be more likely to free-ride (Marwell and Ames, 1981; Frank et al., 1993).
} 
scoring rule), and also received payments for the control tasks. The final payment also included a $€ 5$ participation fee which was enough to cover any possible loss in the experiment.

\subsection{Treatments}

As in Keser and Montmarquette (2011), treatments varied in terms of whether exit was possible, and if so, in terms of the height of barriers to exit. We also varied the payoffs that participants obtained upon successful completion of their project, either the same for both, or different payoffs. There were 5 levels in terms of barriers to exit, and for each of those we looked at two cases in terms of payoffs, symmetric and asymmetric, for a total of 10 treatments (Table 1).

Table 1: Treatments by barriers to exit and individual payoffs.

\begin{tabular}{|c|c|c|c|c|c|}
\hline $\begin{array}{rr}\begin{array}{r}\text { Barriers } \\
\text { to exit }\end{array} \\
\text { Payoffs }\end{array}$ & No exit & $\begin{array}{c}\text { Payoff } 0 \\
\text { in indiv. project }\end{array}$ & $x_{l}=0$ & $x_{l}=2$ & $x_{l}=4$ \\
\hline $\begin{array}{c}\text { Symmetric payoffs } \\
v_{i}=v_{j}=20\end{array}$ & $\begin{array}{l}\text { Treatment } 0, \\
\text { symmetric }\end{array}$ & $\begin{array}{l}\text { Treatment } 1, \\
\text { symmetric }\end{array}$ & $\begin{array}{l}\text { Treatment } 2, \\
\text { symmetric }\end{array}$ & $\begin{array}{c}\text { Treatment } 3, \\
\text { symmetric }\end{array}$ & $\begin{array}{c}\text { Treatment } 4, \\
\text { symmetric }\end{array}$ \\
\hline $\begin{array}{l}\text { Asymmetric payoffs } \\
v_{i}=24, v_{j}=16\end{array}$ & $\begin{array}{l}\text { Treatment } 0, \\
\text { asymmetric }\end{array}$ & $\begin{array}{l}\text { Treatment } 1 \text {, } \\
\text { asymmetric }\end{array}$ & $\begin{array}{l}\text { Treatment } 2, \\
\text { asymmetric }\end{array}$ & $\begin{array}{l}\text { Treatment } 3 \text {, } \\
\text { asymmetric }\end{array}$ & $\begin{array}{l}\text { Treatment } 4, \\
\text { asymmetric }\end{array}$ \\
\hline
\end{tabular}

Barriers to exit. Barriers to exit were manipulated through the function $f_{l}\left(e_{i t}\right)$ that determined the probability of success of the individual project as a function of effort. Treatment 0 was our control treatment, whereby subjects were not allowed to exit the public project. Treatment 1 gave payoff 0 when the subject chose an individual project. In Treatments 2,3 and 4 , probability of success in the individual project was $f_{l}\left(e_{i t}\right)=f\left(e_{i t}+x_{l}\right)=\sqrt{\left(e_{i t}+x_{l}\right) / 22}$ with $x_{l}=\{0,2,4\}$ in treatment $l=\{2,3,4\}$ respectively. We choose 4 as the highest level for $x_{l}$ because beyond that level, having two individual projects is socially more efficient than what can be attained even under the first best with a public project (Section A.1 of the Supplementary Material). The higher the probability of success in an individual project for a given $e_{i t}$, the lower the barriers to exit. Treatment 1 thus exhibits the highest barriers to exit, while Treatment 4 the lowest.

Individual payoffs. For each level of barriers to exit, we ran two sub-treatments, whereby in one case both participants received a payoff of 20 upon successful completion of the project they were involved in (symmetric payoffs), and in the second case one participant obtained a payoff of 16 and the other a payoff of 24 (asymmetric payoffs). The asymmetric treatments were run to assess the robustness of our results, in particular because Nash predictions dramatically change when symmetry in payoff is abandoned (Section A.2 of the Supplementary Material).

\subsection{Terms and notations}

We will use the term "public project" when both participants participate in the public project, and will use the term "public project alone" when a subject is the only one to participate in the public project in a given period. The term "exit" generally refers to choosing an individual project after a period in a public project. A subject will be said to "follow exit" when choosing an individual project after a period when he was alone in the public project. In terms of notations, $e p_{i t}$ denotes agent's $i$ 's effort in the public project at time $t$ and $e p_{j t}^{e}$ denotes agent's $i$ 's expectation about the level of effort devoted by the peer $j$ in the public project. $e p a_{i t}$ is agent's $i$ 's effort in the public project when alone and $e i_{i t}$ is agent's $i$ 's effort in the individual project. Table A.9 lists the names of our variables and their meaning. 


\section{Hypotheses}

To guide our discussion of the results, we develop several hypotheses based on theoretical predictions and the results reported in previous literature:

Hypothesis 1. Public projects will be more efficient in treatments with lower barriers to exit.

Hypothesis 1 is based on the exit literature, which mostly focused on the welfare costs and/or benefits of easier exit. We rely on findings in the closest related experimental literature (My and Chalvignac, 2010; Keser and Montmarquette, 2011). Our hypothesis is weaker than that of many supporters of easy exit: we do not believe that treatments with lower barriers to exit will generate higher overall welfare. This would require not only that surviving public projects in treatments with low barriers to exit be more efficient, but also that dissolution of pairs be efficient. This happens only if pairs that break down are those that are so dysfunctional that both participants benefit by selecting individual work instead. Our hypothesis does not require this to be the case.

Hypothesis 2. Exit from public projects will be driven by the expected opportunity cost of exit.

Hypothesis 2 reflects the Nash predictions of the one-shot version of the public good game when agents are risk neutral (Section A.2 of the Supplementary Material). A myopic and risk neutral agent $i$ with $v_{i} \geq v_{j}$ will choose to stay in the public project in period $t$ if their expected opportunity cost of exit is more than zero:

$$
\underbrace{d_{j t}^{e} \cdot e p_{j t}^{e}-x_{l}}_{\text {expected opportunity cost of exit }}>0
$$

In words, $i$ chooses the public project as long as the expected effort of the peer times the probability she chooses the public project is more than the subsidy to individual projects.

Our next hypotheses are alternative or additional explanations for exit. A first hypothesis considers the impact of beliefs about the effort of the peer.

Hypothesis 3. Exit from public projects will be driven by the difference between one's effort and the expected effort of the peer.

While Hypothesis 2 assumes that exit is driven by questions of efficiency, Hypothesis 3 supposes that a subject cares about issues of payoff distribution and fairness. The difference $e p_{i t}-e p_{j t}^{e}$ indicates how much a subjects believes his peer is exploiting him or he is exploiting his partner. This variable controls for the role of "exploitation aversion" (Fehr et al., 2005) in driving exit from the public project.

A second alternative hypothesis considers the fear that the peer will leave the pairing in the next period.

Hypothesis 4. Exit from public projects will be driven by the fear that the peer will not participate in the public project.

Hypothesis 4 appears to be implied by Hypothesis 2, since lower levels in $d_{j t}^{e}$ imply higher likelihood of exit under that hypothesis. Both factors - fear of exit and opportunity cost of exit - may however play an independent role. A subject who observes the peer leaving may think that the peer has information that she does not have - for example, that working on one's own is more profitable than staying in the pair. She may indeed think she did not fully understand the instructions or did not interpret payoffs correctly. She would then exit as well in order to ascertain 
the consequences of exit. Another possibility is that a subject would leave as retaliation against the decision of the peer to leave. This would lead to subjects following exit by the other even in the absence of monetary incentives to do so.

A final alternative hypothesis considers the direct impact of failure in the public project.

Hypothesis 5. Exit from public projects will be driven by failure in the public project.

When effort is not directly observed, failure may be taken as an indication that the peer exerted lower effort than expected. It may also lead one to believe the peer will leave next period. If those were the only reasons for failure to drive exit, then failure would not independently predict exit. Hypothesis 5 comes into its own only if there is an independent role for failure in driving exit. This is the case if, as hypothesized in the literature on the repeated version of the public good game, subjects enforce high level of effort by punishing (perceived) low effort of the peer. In that case, failure has an impact that is independent of how it drives expectations about effort or likelihood to stay of the peer.

Finally, our last hypothesis allocates the drivers of exit as a function of the height of barriers to exit:

Hypothesis 6. Opportunity costs of exit will be more important as a driver of exit in treatments with low barriers to exit. The converse will hold for failure as a driver of exit.

Hypothesis 6 is inspired by Hirschman (1970): Exit is both a way to voice dissatisfaction (as per Hypothesis 5) and a way to escape a dysfunctional team (as per Hypothesis 2). Hirschman (1970) observed that the greater the availability of exit, the less likely voice would be used. Yamagishi (1988) made some related point when contrasting collectivist and individualistic drivers of exit. Collectivist motivation for exit is driven by wanting to make the pairing work better by influencing the behavior of the peer. Individualistic motivation for exit is driven by payoff considerations and takes the behavior of the other as given. We could also call one set of motives "optimistic" about the ability of the peer to respond to pressure towards cooperation and the other "pessimistic" about the ability of the peer to change his behavior. Under Hypothesis 6, high barriers to exit give participants a higher sense of self-efficacy in public projects because the peer cannot leave easily so that sanctions are effective. This will lead them to undertake to influence the peer by their actions, including by exiting (Kerr and Kaufman-Gilliland, 1997). Low barriers to exit will lower the sense of self-efficacy of our subjects, so that without the prospect of the possibility for others to change behavior, subjects will take present expected behavior as the basis for their decision to exit.

\section{Results}

316 subjects took part in 10 experimental sessions that were run in the laboratory of the Max Planck Institute for Economics in Jena (Germany). Almost all subjects were university students in Jena, $55 \%$ of them were female, the average age was 24 , and $16 \%$ were studying economics or business. Randomization checks confirmed that this composition did not differ significantly across treatments. Average remuneration was $€ 15$ for an experiment that lasted about one hour and a half. Hourly wage was therefore slightly more than that of a research assistant. The experiment was computerized using the Zurich Toolbox for Ready-made Economic Experiments (z-Tree, Fischbacher, 2007) and subjects were recruited using the Online Recruitment System for Economic Experiments (ORSEE, Greiner, 2004). Translated English instructions are provided in Section B.1 of the Supplementary Material. ${ }^{3}$

\footnotetext{
${ }^{3}$ The experimental software and the original German instructions are available upon request.
} 


\subsection{The patterns of exit}

The patterns of exit varied by treatment. Figure 2 gives an overview of the prevalence of exit by treatment and over the different matchings and periods.

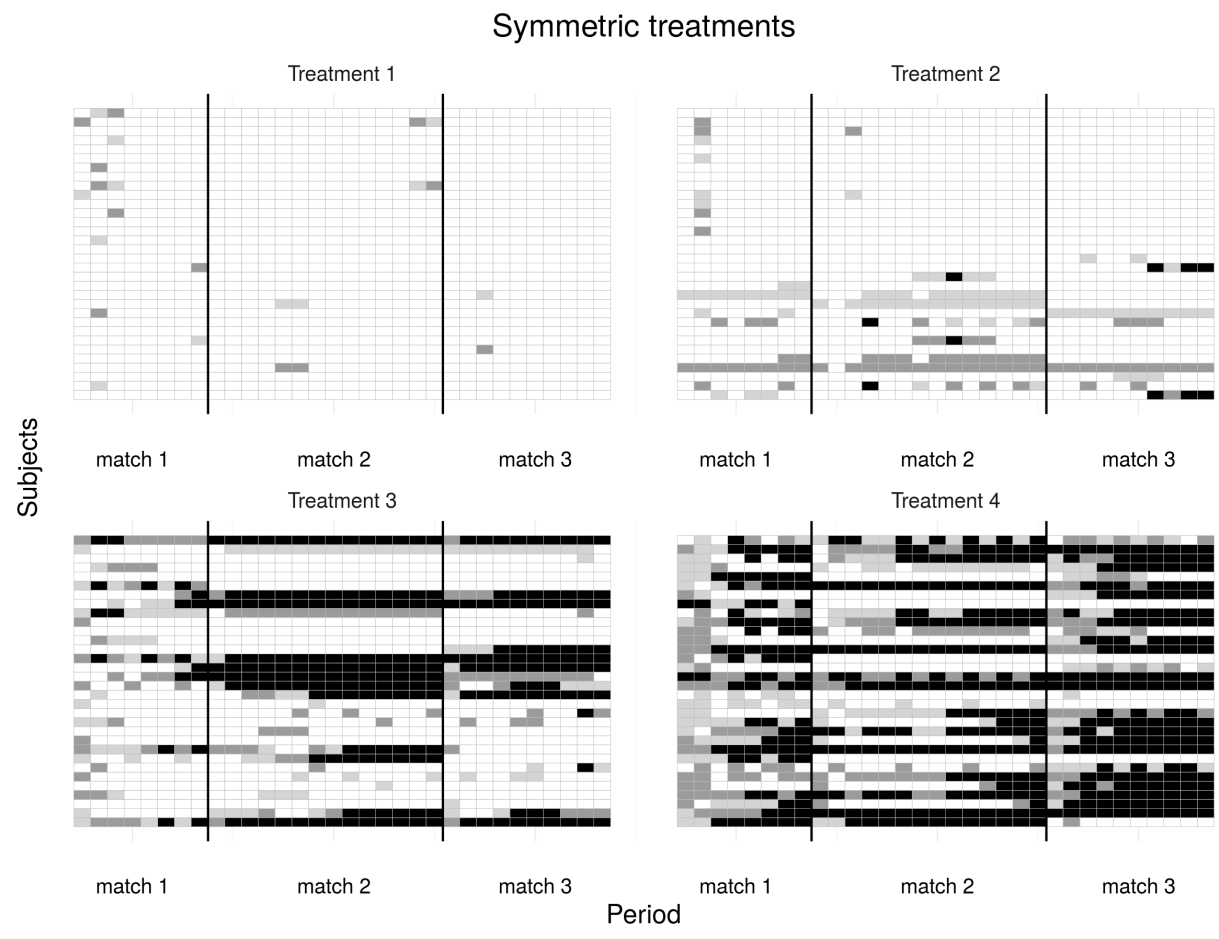

Asymmetric treatments

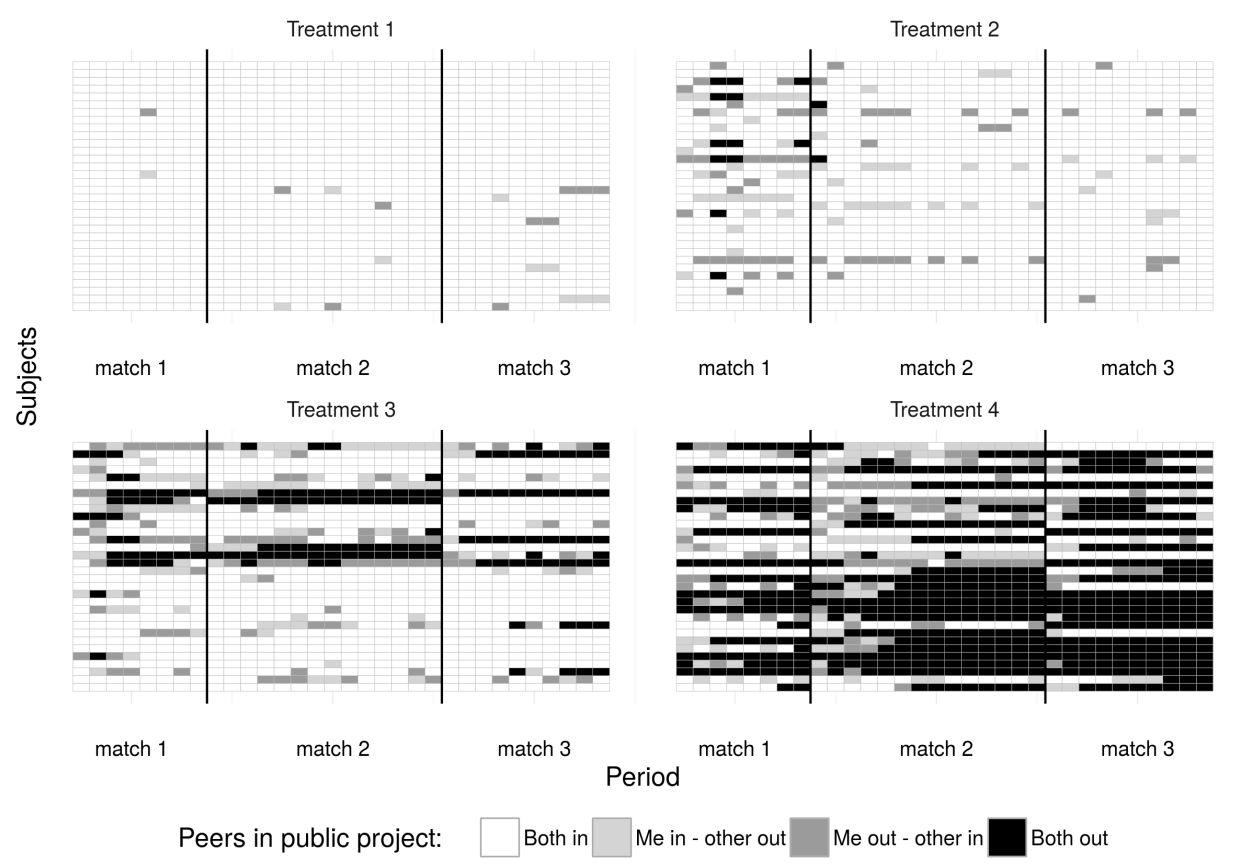

Figure 2: Project choice by individuals over time, by treatment

Figure 2 represents the evolution of participation in the public project over time across treatments. Each point on the horizontal axis is a period, and each point on the vertical axis is an individual. Vertical lines separate each of the three matchings. The darker the panels, the more exit was prevalent. We find that 50 of 64 participants never left the public project in Treatment 1. 
This number drops to 32 in Treatment 2, 16 in Treatment 3, and 2 in Treatment 4 . At the other extreme, no one always chose the private project in Treatments 1 and 2, but 2 did so in Treatment 3 and 10 did so in Treatment 4. Finally, an additional small number of subjects can be defined as strict followers, that is, they exit the public project only if their peer left it last period and join it only if their peer joined it last period. Those are 3 participants in Treatment 1, 3 in Treatment 2, 7 in Treatment 3 and 5 in Treatment 4 . All other participants chose to stay or exit based not only on the decision of their peer or on a strict preference for one type of project or the other, but also based on other factors. Those are 11 participants in Treatment 1, 29 in Treatment 2, 39 in Treatment 3, and 47 in Treatment 4 . We will capture the behavior of those other participants later on in our regressions.

Table 2 gives further summary statistics on the exit behavior of subjects by treatment.

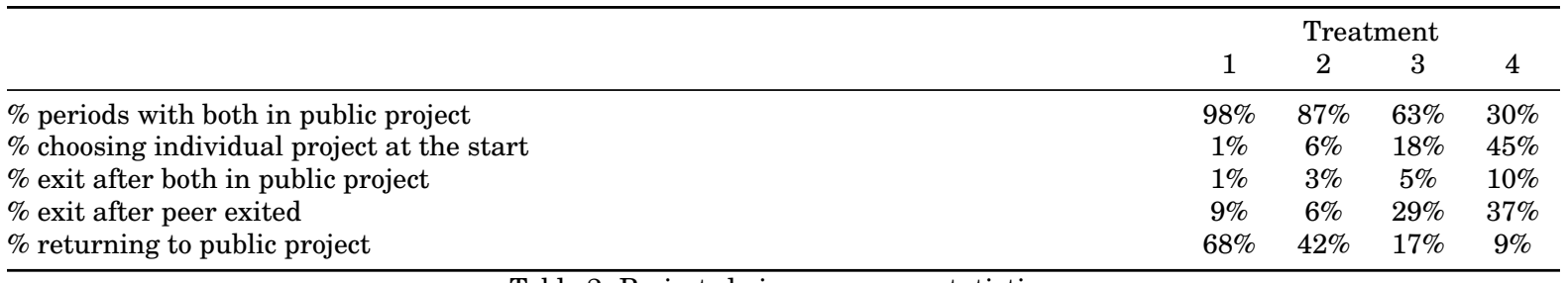

Table 2: Project choice, summary statistics.

We find that the proportion of periods with both subjects in the public project gradually declined as barriers to exit were lowered, from $98 \%$ in Treatment 1 to $30 \%$ in Treatment 4 . This is because more subjects chose individual projects at the outset of a matching (from 1\% in Treatment 1 to $45 \%$ in Treatment 4), and subjects became more likely to initiate exit from the public project (only $1 \%$ of periods with a common project were followed by exit in Treatment 1, vs. $10 \%$ in Treatment 4). Subjects in Treatments 3 and 4, which had lower barriers to exit, were also more likely to exit after their peer exited, and less likely to choose to return to the public project after having exited.

\subsection{The inefficiency of exit}

Table 3 shows average payoffs across treatments depending on which project the subjects participated in as well as overall. Payoffs are shown in ECU, whereby 1 ECU $=€ 0.50$.

Table 3: Average payoff in ECU and its components, by treatment.

\begin{tabular}{cccccc}
\hline \multirow{2}{*}{ Treatment } & Statistics & $\begin{array}{c}\text { payoff } \\
\text { public }\end{array}$ & $\begin{array}{c}\text { payoff public } \\
\text { alone }\end{array}$ & $\begin{array}{c}\text { payoff } \\
\text { individual }\end{array}$ & $\begin{array}{c}\text { average } \\
\text { payoff }\end{array}$ \\
\hline \multirow{2}{*}{0} & mean (sd) & $7.9(9.5)$ &. &. & $7.9(9.5)$ \\
& $\mathrm{N}$ & 1920 & 0 & 0 & 1920 \\
1 & mean (sd) & $8.0(9.4)$ & $3.7(9.7)$ & $-1.1(2.6)$ & $7.9(9.4)$ \\
& $\mathrm{N}$ & 2004 & 22 & 22 & 2048 \\
2 & mean (sd) & $8.0(9.6)$ & $3.7(9.3)$ & $4.4(10.0)$ & $7.4(9.7)$ \\
& $\mathrm{N}$ & 1778 & 123 & 147 & 2048 \\
3 & mean (sd) & $8.2(9.3)$ & $2.7(9.3)$ & $5.8(10.0)$ & $7.1^{* *}(9.7)$ \\
& $\mathrm{N}$ & 1300 & 189 & 559 & 2048 \\
4 & mean (sd) & $8.1(9.5)$ & $4.0(9.9)$ & $7.4(9.7)$ & $7.2^{*}(9.7)$ \\
& $\mathrm{N}$ & 610 & 246 & 1192 & 2048 \\
\hline
\end{tabular}

Difference w.r.t. Treatment $0:{ }^{+} p<0.10,{ }^{*} p<0.05,{ }^{* *} p<0.01,{ }^{* * *} p<0.001$

We report Satterthwaite's $t$ test for data with unequal variances to test equality in means. Differences are also significant under the Wilcoxon rank-sum test and the Kolgomorov-Smirnov test.

There was no significant difference across treatments in the average payoff obtained from participation in the public project. Those payoffs varied only between 7.9 ECU in Treatment 0 and 
8.2 ECU in Treatment 3. Payoffs when alone in the public project also did not vary significantly across treatments. Payoff in an individual project increased from Treatment 1 to 4 thanks to higher subsidy $x_{l}$ but remained lower than when in a public project. This meant that individuals were on average worse off in treatments with lower barriers to exit: average individual payoff decreased from 7.9 ECU in Treatments 0 and 1 to 7.4 ECU in Treatment 2 and 7.1-7.2 ECU in Treatments 3 and 4 .

Result 1. There were no significant differences in average payoffs in public projects depending on the treatment (Hypothesis 1). Average individual welfare was lower in treatments with lower barriers to exit.

Inaccurate expectations explain why welfare decreased as exit became more frequent. Table 4 shows the average difference between expected effort by the peer before exit $\left(e p_{j t}^{e}\right)$ and actual effort of the peer before exit $\left(e p_{j t}\right)$, as well as the average difference between the expected participation decision of the peer $\left(d_{j t}^{e}\right)$ and the actual participation decision $\left(d_{j t}\right)$ at the time of exit.

Table 4: Statistics upon exit, by treatment.

\begin{tabular}{|c|c|c|c|c|}
\hline Treatment & 1 & 2 & 3 & 4 \\
\hline$e p_{j t-1}^{e}-e p_{j t-1}$ & 0.12 & 0.31 & $0.87 *$ & 0.57 \\
\hline$d_{j t}^{e}-d_{j t}$ & $-19.6 \% * *$ & $-19.9 \% * * *$ & $-20.6 \% * * *$ & $-28.8 \% * * *$ \\
\hline Number of exits & 15 & 57 & 60 & 61 \\
\hline Exits s.t. $e p_{j t-1}^{e}>x_{l}$ & - & 55 & 54 & 49 \\
\hline
\end{tabular}

We see that exit does not appear to have been due to inaccurate beliefs about the effort of the peer (first row) but rather to over-pessimistic beliefs about the likelihood of exit of the peer (second row). This exaggerated fear of being left alone means that a majority of exits happened even when subjects believed their peer did enough effort to justify staying in if the peer also stayed in. This is revealed by a comparison of the total number of exit in each treatment (third row) with the number of those exit that happened even though $e p_{j t-1}^{e}>x_{l}$ (fourth row). ${ }^{4}$ With reference to formula 1 determining the expected opportunity cost of exit, the main explanation for excessive exit therefore was that subjects over-estimated the likelihood that their peer would leave the pair. Pessimistic beliefs about the peer's participation decisions led subjects to leave public projects more often than justified by actual peer behavior.

This fear of being left alone can be likened to betrayal aversion (Bohnet et al., 2008) or exploitation aversion (Fehr et al., 2005). In Treatment 1, staying in the public project was advantageous while in Treatment 2, staying alone in the public project gave the same expected payoff for a given level of effort than being in a private project. However, a subject left alone in the public project did not have the same opportunities as their peer in Treatments 3 and 4, as he did not receive subsidy $x_{l}>0$ to private projects. Therefore a subject left alone may have felt betrayed and disadvantaged. There was also a psychological cost to being left alone in all treatments, as a subject may have felt rejected by their peer. Subjects may therefore have dealt with this fear by taking the initiative to leave rather than facing being left.

\footnotetext{
${ }^{4}$ We rely here on beliefs about effort in the period before exit as a proxy for beliefs in the period when exit occurred. We obtain very similar statistics when using estimates $e \hat{p}_{j t}^{e}$ of $e p_{j t}^{e}$ at the time of exit from NLS regressions with selection correction and when estimating $e p_{j t}^{e}$ at the time of exit from individual average response to failure and success in the public project in terms of beliefs $e p_{j t}^{e}$.
} 


\subsection{The drivers of exit}

We assess econometrically how far exit was due to myopic payoff considerations (Hypothesis 2) and how far it was motivated by punishment (Hypothesis 5). We also test Hypothesis 3 by including variable $e p_{i t}-e p_{j t}^{e}$ in our regressions, and Hypothesis 4 by including expected probability $d_{j t}^{e}$ that the peer participates in the public project.

Steps in our regression procedure are explained in Section A.4 of the Supplementary Material. In particular, estimates $e \hat{p}_{j t}^{e}$ of the effort "I" would have expected "my" peer to exert in the public good if "I" had not left, are obtained using a non-linear least square estimator following Semykina and Wooldridge (2013). Our regressions use estimates of expected opportunity cost of exit along Formula 1. Results are shown in Table 5, which shows the effect of our variables on the project participation decision $d_{i t}$ of our subjects over time. 
Table 5: Determinants of the decision to take part in the public project, marginal effects

\begin{tabular}{|c|c|c|c|c|}
\hline dependent variable & $\begin{array}{l}\text { (1) POOLED } \\
\partial d_{i t} / \partial v a r\end{array}$ & $\begin{array}{c}\text { (2) } \mathrm{PA} \\
\partial d_{i t} / \partial v a r\end{array}$ & $\begin{array}{c}(3) \mathrm{FE} \\
d_{i t}(\text { see note } 1)\end{array}$ & $\begin{array}{c}\text { (4) } \mathrm{RE} \\
\left.\partial d_{i t} / \partial \operatorname{var} \text { (see note } 2\right)\end{array}$ \\
\hline$d_{j t}^{e}$ & $\begin{array}{l}0.1009 \\
(1.55)\end{array}$ & $\begin{array}{l}0.0247 \\
(0.45)\end{array}$ & $\begin{array}{l}0.1039 \\
(0.08)\end{array}$ & $\begin{array}{l}0.0546 \\
(1.09)\end{array}$ \\
\hline$d_{j t}^{e} \times e \hat{p}_{j t}^{e}-x_{l}$ & $\begin{array}{l}0.0327 * * \\
(3.07)\end{array}$ & $\begin{array}{l}0.0416 * * * \\
(4.43)\end{array}$ & $\begin{array}{l}0.8271 * * * \\
(3.63)\end{array}$ & $\begin{array}{l}0.0358 * * * \\
(3.94)\end{array}$ \\
\hline$s p_{i t-1}$ & $\begin{array}{l}0.0436 * * * \\
(7.11)\end{array}$ & $\begin{array}{l}0.0285 * * * \\
(4.76)\end{array}$ & $\begin{array}{l}0.5510 * * * \\
(5.30)\end{array}$ & $\begin{array}{l}0.0317 * * * \\
(5.66)\end{array}$ \\
\hline$e p_{i t-1}-e p_{j t-1}^{e}$ & $\begin{array}{l}-0.0116 * * * \\
(-3.38)\end{array}$ & $\begin{array}{l}-0.0107 * * * \\
(-3.30)\end{array}$ & $\begin{array}{l}-0.1587 * * * \\
(-3.40)\end{array}$ & $\begin{array}{l}-0.0085 * * * \\
(-3.61)\end{array}$ \\
\hline per & $\begin{array}{l}-0.0047 * * * \\
(-4.13)\end{array}$ & $\begin{array}{l}-0.0062 * * * \\
(-4.66)\end{array}$ & $\begin{array}{l}-0.0969 * * * \\
(-4.61)\end{array}$ & $\begin{array}{l}-0.0051 * * * \\
(-5.23)\end{array}$ \\
\hline phase 2 & $\begin{array}{l}0.0045 \\
(0.38)\end{array}$ & $\begin{array}{l}0.0149 \\
(1.14)\end{array}$ & $\begin{array}{l}0.1722 \\
(0.83)\end{array}$ & $\begin{array}{l}0.0095 \\
(0.80)\end{array}$ \\
\hline phase 3 & $\begin{array}{l}-0.0019 \\
(-0.17)\end{array}$ & $\begin{array}{l}0.0080 \\
(0.65)\end{array}$ & $\begin{array}{l}0.1147 \\
(0.51)\end{array}$ & $\begin{array}{l}0.0041 \\
(0.37)\end{array}$ \\
\hline$v$ & $\begin{array}{l}-0.0031 \\
(-0.89)\end{array}$ & $\begin{array}{l}-0.0036 \\
(-1.07)\end{array}$ & . & $\begin{array}{l}-0.0026 \\
(-0.96)\end{array}$ \\
\hline Treatment 2 & $\begin{array}{l}-0.1088 * \\
(-2.46)\end{array}$ & $\begin{array}{l}-0.1128 * \\
(-2.49)\end{array}$ & . & $\begin{array}{l}-0.0601+ \\
(-1.81)\end{array}$ \\
\hline Treatment 3 & $\begin{array}{l}-0.1213 * * \\
(-2.99)\end{array}$ & $\begin{array}{l}-0.1264 * * \\
(-3.13)\end{array}$ & . & $\begin{array}{l}-0.0777 * \\
(-2.37)\end{array}$ \\
\hline Treatment 4 & $\begin{array}{l}-0.0953+ \\
(-1.76)\end{array}$ & $\begin{array}{l}-0.0866+ \\
(-1.67)\end{array}$ & . & $\begin{array}{l}-0.0578 \\
(-1.38)\end{array}$ \\
\hline female & $\begin{array}{l}-0.0198 \\
(-0.88)\end{array}$ & $\begin{array}{l}-0.0214 \\
(-0.94)\end{array}$ & . & $\begin{array}{l}-0.0297 \\
(-1.63)\end{array}$ \\
\hline age & $\begin{array}{l}0.0004 \\
(0.19)\end{array}$ & $\begin{array}{l}0.0004 \\
(0.15)\end{array}$ & . & $\begin{array}{l}0.0004 \\
(0.24)\end{array}$ \\
\hline economist & $\begin{array}{l}0.0026 \\
(0.10)\end{array}$ & $\begin{array}{l}0.0070 \\
(0.26)\end{array}$ & . & $\begin{array}{l}-0.0007 \\
(-0.03)\end{array}$ \\
\hline$r a$ & $\begin{array}{l}-0.0024 \\
(-0.26)\end{array}$ & $\begin{array}{l}-0.0026 \\
(-0.30)\end{array}$ & . & $\begin{array}{l}-0.0031 \\
(-0.46)\end{array}$ \\
\hline$s u$ & $\begin{array}{l}-0.0074+ \\
(-1.67)\end{array}$ & $\begin{array}{l}-0.0079+ \\
(-1.81)\end{array}$ & . & $\begin{array}{l}-0.0069 \\
(-1.54)\end{array}$ \\
\hline $\begin{array}{l}\text { svo } \\
\text { trust }\end{array}$ & $\begin{array}{l}-0.0274 \\
(-0.62) \\
-0.0022 \\
(-0.37)\end{array}$ & $\begin{array}{l}-0.0324 \\
(-0.80) \\
-0.0011 \\
(-0.17)\end{array}$ & . & $\begin{array}{l}-0.0159 \\
(-0.39) \\
-0.0020 \\
(-0.34)\end{array}$ \\
\hline$N$ & 7254 & 7254 & 3999 & 7254 \\
\hline Subjects & 234 & 234 & 129 & 234 \\
\hline$l l$ & -1783.5 & & -985.0 & -1421.6 \\
\hline$d f$ & 18 & 18 & 7 & 18 \\
\hline Wald test $\chi^{2}$ & $487.5 * * *$ & $321.2 * * *$ & $337.3 * * *$ & $441.2 * * *$ \\
\hline Lagrange multiplier test & 3.18 & 3.21 & 0.63 & 1.69 \\
\hline $\operatorname{Pr}\left(\hat{d_{i t}}=1 \mid d_{i t}=1\right)$ & $95.9 \%$ & $96.3 \%$ & $81.8 \%$ & $96.3 \%$ \\
\hline $\operatorname{Pr}\left(\hat{d}_{i t}=0 \mid d_{i t}=0\right)$ & $64.9 \%$ & $61.8 \%$ & $75.6 \%$ & $62.1 \%$ \\
\hline
\end{tabular}

$z$ statistics in parentheses, bootstrapped standard errors, 200 replications.

$+p<0.10,{ }^{*} p<0.05,{ }^{* *} p<0.01,{ }^{* * *} p<0.001$

Marginal effects are obtained by the delta method. $\partial d_{i t} / \partial v a r$ for factor levels is the discrete change from the base level. ${ }^{1}$ In FE, we report parameter estimates for the logit model. FE regressions exclude 105 subjects who chose $d_{i t}=1$ for every period $>1 .^{2}$ In RE, marginal effects are computed assuming that individual effects $u_{i}$ are equal to 0 . The Lagrange multiplier test is obtained by doing a Wald test of zero coefficient for the added regressor $\left(\operatorname{var}^{\prime} \hat{\beta}\right)^{2}$.

We find that the coefficient on expected opportunity costs of exit $d_{j t}^{e} \times e \hat{p}_{j t}^{e}-x_{l}$ in our regressions is consistently positive and significantly different from zero.

Result 2. Opportunity costs of exit were a driver of exit (Hypothesis 2).

With reference to Table 6, which breaks down regression results by treatment, we find that this is so only in treatments with low barriers to exit (Treatments 3 and 4). Exit in Treatments 1 and 2 occurred even for high expected opportunity costs. Exit is therefore unlikely to have been driven by a cost-benefit analysis in treatments with high barriers to exit. We also find that the frequency of exit was more sensitive to variations in expected opportunity costs of exit in Treatment 4 than in Treatment 3. Hypothesis 2 thus appears to be verified in treatments with low barriers to exit 
but not so in treatments with high barriers to exit. ${ }^{5}$

We also find that the coefficient on the difference between own effort in the public project $e p_{i t-1}$ and belief about effort of the peer $e p_{j t-1}^{e}$ is consistently positive and significantly different from zero. However, the marginal effect of this variable is lower than that of opportunity costs of exit.

Result 3. Aversion to being exploited generated exit (Hypothesis 3)

Belief that the peer was free riding, measured by perceived excess effort $\left(e p_{i t-1}-e p_{j t-1}^{e}\right)$, therefore appears to have motivated exit from public projects. This is not the case however in Treatment 1 (Table 6).

The coefficient on variable $d_{j t}^{e}$, the expected likelihood of exit of the partner, leads to the following result:

Result 4. Subjects were not independently driven to exit by a fear of being left alone in the public project (Hypothesis 4).

This result is surprising as univariate correlation of variable $d_{j t}^{e}$ with exit decision shows that subjects were more likely to exit if they expected their peer to do so as well. However, our multivariate regressions show that Hypothesis 4 does not play an independent role in motivating exit. The effect of expected exit of the peer on "my" decision to exit is therefore mediated by its impact on "my" expected opportunity costs of exit.

Finally, we find that $s p_{i t-1}$, success in the public project last period, made staying in more likely. Conversely therefore, failure motivated exit.

\section{Result 5. Success of the public project lowered the likelihood of exit (Hypothesis 5).}

This impact of failure is independent of how failure drove down expectations about the effort exerted by the peer. Indeed, we already took this effect into account by computing estimates $e \hat{p}_{j t}^{e}$ at the time of exit and inputting those estimates in the expected opportunity cost of exit. Combined with the fact that exit was apparently not driven by cost-benefit considerations in Treatments 1 and 2, we find support for the hypothesis that exit is likely to have been meant as a punishment for failure in the public project as per Hypothesis 5. Further regressions (not shown) show that failures occurring after previous failures did not make exit more likely compared to just one failure. However, strings of successes made exit ever less likely compared to just one success.

Behavior under Hypothesis 5 may have been motivated by the belief that exit would act as a motivational tool. However, we find no such motivational effect; exit did not promote cooperation. Indeed, subjects who were left alone in the public project did not exert higher effort in the public project upon return of their peer to the public project. We see this when running regressions for effort in public projects (Table A.12 in the Supplementary Material). Variable $1-d_{j t}$, which takes value 1 if the peer was in an individual project last period, is not associated with higher effort in the public project, except in Treatment 3. Further reducing the potential effectiveness of exit as a motivational tool, only few exits were followed by a return (cf. Table 2 ).

\footnotetext{
${ }^{5}$ We rely here on beliefs about effort in the period before exit as a proxy for beliefs in the period when exit occurred. We obtain a very similar conclusion when using estimates $e \hat{p}_{j t}^{e}$ of $e p_{j t}^{e}$ at the time of exit from non-linear least square regressions with selection correction and when estimating $e p_{j t}^{e}$ at the time of exit from individual average response to failure and success in the public project in terms of beliefs $e p_{j t}^{e}$.
} 
Our results show that success in the public project and higher expected exit costs both made staying in the public project more likely, while failure made staying less likely. This confirms Hypotheses 2 and 5. We find however that Hypothesis 4 is not verified: Changes in expected participation $d_{j t}^{e}$ of the peer did not appear to have an independent effect. Finally, Hypothesis 3 is verified; belief that one is being exploited did play an independent role in motivating exit.

We checked our results for various controls. We find that value $v$ derived from the project does not appear to make a subject more likely to exit. This is the case whether we use value $v$ in our regressions or if we assign dummies for subjects with value 16 and subjects with value 24 . Time spent within a pairing (per) tends to make it more likely one will exit the public good, but there is no difference in likelihood to exit across phases. Age, gender, education (economist), levels of risk aversion $(r a)$ and aversion to strategic uncertainty $(s u)$, social value orientation $(s v o)$ and level of trust in others (trust) did not appear to influence the decision of our subjects.

\subsection{How barriers to exit affected the drivers of exit.}

We test Hypothesis 6 by breaking down the regressions results by treatment. We show marginal effects for population averaged regressions in Table 6. Population averaged estimates tell us how changing the value of a variable affects the probability that a participant picked at random would be in the public project. Fixed effect estimates tell us how changing the value of a variable affects the decision of a given participant. Parameter estimates for within-subject regressions are however very similar to those from population-average regressions. We comment on the results of the population averaged regressions as they are more relevant to a discussion of aggregate behavior. 
Table 6: Determinants of the decision to take part in the public project, population-averaged regressions, marginal effects, by treatment.

\begin{tabular}{|c|c|c|c|c|}
\hline Dependent variable & $\begin{array}{l}\text { (1) TREATMENT } 1 \\
\partial d_{i t} / \partial v a r\end{array}$ & $\begin{array}{l}\text { (2) TREATMENT } 2 \\
\partial d_{i t} / \partial v a r\end{array}$ & $\begin{array}{l}\text { (3) TREATMENT } 3 \\
\partial d_{i t} / \partial v a r\end{array}$ & $\begin{array}{c}\text { (4) TREATMENT } 4 \\
\partial d_{i t} / \partial v a r\end{array}$ \\
\hline$d_{j t}^{e}$ & $\begin{array}{l}0.0040 \\
(0.13)\end{array}$ & $\begin{array}{l}0.1068 \\
(0.94)\end{array}$ & $\begin{array}{l}-0.0320 \\
(-0.18)\end{array}$ & $\begin{array}{l}-0.2488 \\
(-0.94)\end{array}$ \\
\hline$d_{j t}^{e} \times e \hat{p}_{j t}^{e}-x_{l}$ & $\begin{array}{l}0.0049 \\
(1.00)\end{array}$ & $\begin{array}{l}0.0059 \\
(0.31)\end{array}$ & $\begin{array}{l}0.0758 * \\
(2.40)\end{array}$ & $\begin{array}{l}0.1272 * * \\
(2.68)\end{array}$ \\
\hline$s p_{i t-1}$ & $\begin{array}{l}0.0046 \\
(0.87)\end{array}$ & $\begin{array}{l}0.0280+ \\
(1.81)\end{array}$ & $\begin{array}{l}0.0442 * * \\
(2.65)\end{array}$ & $\begin{array}{l}0.0412+ \\
(1.91)\end{array}$ \\
\hline$e p_{i t-1}-e p_{j t-1}^{e}$ & $\begin{array}{l}-0.0008 \\
(-0.52)\end{array}$ & $\begin{array}{l}-0.0094 \\
(-1.63)\end{array}$ & $\begin{array}{l}-0.0173 * \\
(-2.01)\end{array}$ & $\begin{array}{l}-0.0227 * * \\
(-2.66)\end{array}$ \\
\hline per & $\begin{array}{l}-0.0008 \\
(-0.71)\end{array}$ & $\begin{array}{l}-0.0006 \\
(-0.32)\end{array}$ & $\begin{array}{l}-0.0079 * \\
(-2.43)\end{array}$ & $\begin{array}{l}-0.0207 * * * \\
(-4.72)\end{array}$ \\
\hline phase 2 & $\begin{array}{l}0.0077 \\
(0.84)\end{array}$ & $\begin{array}{l}0.0289+ \\
(1.80)\end{array}$ & $\begin{array}{l}-0.0192 \\
(-0.58)\end{array}$ & $\begin{array}{l}0.0568 \\
(1.26)\end{array}$ \\
\hline phase 3 & $\begin{array}{l}0.0045 \\
(0.47)\end{array}$ & $\begin{array}{l}0.0479+ \\
(1.84)\end{array}$ & $\begin{array}{l}0.0071 \\
(0.21)\end{array}$ & $\begin{array}{l}-0.0386 \\
(-0.81)\end{array}$ \\
\hline$v$ & $\begin{array}{l}0.0018 \\
(0.61)\end{array}$ & $\begin{array}{l}-0.0045 \\
(-0.61)\end{array}$ & $\begin{array}{l}-0.0146 \\
(-1.42)\end{array}$ & $\begin{array}{l}-0.0030 \\
(-0.22)\end{array}$ \\
\hline female & $\begin{array}{l}0.0020 \\
(0.11)\end{array}$ & $\begin{array}{l}-0.0278 \\
(-0.35)\end{array}$ & $\begin{array}{l}-0.0551 \\
(-0.98)\end{array}$ & $\begin{array}{l}0.0100 \\
(0.14)\end{array}$ \\
\hline age & $\begin{array}{l}0.0019 \\
(0.47)\end{array}$ & $\begin{array}{l}0.0062 \\
(0.55)\end{array}$ & $\begin{array}{l}-0.0064 \\
(-0.54)\end{array}$ & $\begin{array}{l}0.0031 \\
(0.28)\end{array}$ \\
\hline economist & $\begin{array}{l}-0.0001 \\
(-0.01)\end{array}$ & $\begin{array}{l}-0.0013 \\
(-0.01)\end{array}$ & $\begin{array}{l}-0.0109 \\
(-0.14)\end{array}$ & $\begin{array}{l}0.0363 \\
(0.35)\end{array}$ \\
\hline ra & $\begin{array}{l}-0.0022 \\
(-0.22)\end{array}$ & $\begin{array}{l}0.0015 \\
(0.09)\end{array}$ & $\begin{array}{l}0.0061 \\
(0.32)\end{array}$ & $\begin{array}{l}-0.0151 \\
(-0.37)\end{array}$ \\
\hline$s u$ & $\begin{array}{l}0.0014 \\
(0.28)\end{array}$ & $\begin{array}{l}-0.0101 \\
(-1.01)\end{array}$ & $\begin{array}{l}-0.0142 \\
(-1.07)\end{array}$ & $\begin{array}{l}-0.0031 \\
(-0.15)\end{array}$ \\
\hline svo & $\begin{array}{c}0.0037 \\
(0.17)\end{array}$ & $\begin{array}{l}-0.0469 \\
(-0.44)\end{array}$ & $\begin{array}{l}0.0465 \\
(0.41)\end{array}$ & $\begin{array}{l}-0.1351 \\
(-0.86)\end{array}$ \\
\hline trust & $\begin{array}{l}-0.0013 \\
(-0.31)\end{array}$ & $\begin{array}{l}-0.0121 \\
(-0.63)\end{array}$ & $\begin{array}{l}0.0114 \\
(0.71)\end{array}$ & $\begin{array}{l}-0.0216 \\
(-0.65)\end{array}$ \\
\hline$N$ & 1984 & 1984 & 1829 & 1457 \\
\hline Subjects & 64 & 64 & 59 & 47 \\
\hline$d f$ & 15 & 15 & 15 & 15 \\
\hline Wald test $\chi^{2}$ & $22.55+$ & $43.33 * * *$ & $66.00 * * *$ & $68.55 * * *$ \\
\hline Lagrange multiplier test & 0.87 & $6.66 * *$ & 0.0 & 0.52 \\
\hline $\operatorname{Pr}\left(\hat{d_{i t}}=1 \mid d_{i t}=1\right)$ & $100.0 \%$ & $99.9 \%$ & $94.2 \%$ & $81.0 \%$ \\
\hline $\operatorname{Pr}\left(\hat{d}_{i t}=0 \mid d_{i t}=0\right)$ & $0.0 \%$ & $2.8 \%$ & $62.5 \%$ & $79.3 \%$ \\
\hline
\end{tabular}

$z$ statistics in parentheses, bootstrapped standard errors, 200 replications.

Marginal effects are obtained by the delta method. $\partial d_{i t} / \partial v a r$ for factor levels is the discrete change from the base level.

The Lagrange multiplier test is obtained by doing a Wald test of zero coefficient for the added regressor $\left(\text { var }^{\prime} \hat{\beta}\right)^{2}$.

$+p<0.10,^{*} p<0.05,{ }^{* *} p<0.01,{ }^{* * *} p<0.001$

A comparison of the marginal effect of the different drivers of exit across treatments leads us to express the following result:

Result 6. Expected opportunity costs of exit played an increasingly significant role in driving exit as the barriers to exit were lowered across treatments. However, there was no corresponding decline in the role of exit as punishment for failure across treatments (Hypothesis 6).

Overall, lower barriers to exit led subjects to be more sensitive to payoff comparisons, both across options - payoff from staying in vs. payoff from exiting - and across participants - payoff of the peer vs. "my" own payoff. However, subjects were always more willing to stay in case of success compared to the case of failure. They kept on reacting to failure and success in a way that was consistent with wanting to promote cooperation over the long term. This is independent of how failure affected their beliefs, as this is controlled for by other variables in our regressions. Those findings are robust even when considering only experienced subjects by excluding the first matching in the experiment (results not shown). This partial verification of Hypothesis 3 lends support to Tenbrunsel and Messick (1999) who argue that allowing exit may frame collaboration as a self-interest 
competition, thus leading subjects to leave if they feel subjected to distributive injustice.

Beyond establishing the role of various hypothesized drivers of exit, we clarified in this section the relationship between the drivers of exit and barriers to exit. As suggested by Yamagishi (1988), we found that whether one motivation or the other was prevalent depended on how easy or difficult exit was. Making exit more attractive by increasing the return on individual work did not only make exit more frequent, but also changed the motivations for exit. This is because if exit is easy, then not only is the investment in improving the functioning of the pair likely to be lost as the pair may irrevocably dissolve, but the meaning of exit also becomes ambivalent, as it is not clear if it is meant as a punishment or if it means one is not ready to work together anymore. Easy exit thus lowers one's ability to influence the action of others in public projects and therefore makes participants focus on comparisons of payoffs between individual and public projects and comparisons of payoff between themselves and the peer.

\section{Conclusion}

We examined the dynamics of cooperation and exit in a public good game with stochastic outcomes and imperfect monitoring of the action of others. We varied the barriers to exit across treatments in order to see how this influenced the level of cooperation within pairings as well as their stability.

We found that individuals in treatments with low barriers to exit obtained lower welfare than subjects in treatments with high barriers to exit. This is because exit occurred mainly when staying in would have been more efficient, and because low barriers to exit did not motivate participants to try to reduce the risk of exit by the peer by contributing more to the public projects. Subjects underestimated the payoff from staying. This was in large part because they had an exaggerated fear of being left alone in the collaborative project.

We looked for a range of drivers of exit and determined that exit was driven both by the difference in expected payoff between being alone or together and by whether joint work was successful in the previous period. Low barriers to exit made subjects more sensitive to payoff comparisons across individual and joint work and to differences in effort between themselves and their peer. Success and failure played an independent role in motivating exit in all treatments. Indeed, it was a significant determinant of project choice even after taking into account the impact of good and bad outcomes on the beliefs of participants about their peer.

Our first main contribution is to have identified an original source of inefficiency in public good games with an exit option: Subjects over-estimate the likelihood their peer will leave the pairing and they therefore preempt exit by exiting first. The risk of being left alone is a social risk, as another human being is the primary source of uncertainty (Bohnet et al., 2008). That risk is similar to the risk of being betrayed or exploited, and the main issue we identified here is that subjects overestimated this risk.

Our second main contribution is to have allocated weights to different drivers of exit as a function of the level of barriers to exit. We confirmed that low barriers to exit threaten the cohesion of groups because they prompt individuals to focus on the present situation and to give more importance to their own short-term individual interests. A lesson from our experiment is that individuals who enter a joint project should anticipate the lack of trust of their partner in their willingness to stay in. This should encourage them to put limits on their own freedom to exit in order to help their partner maintain confidence and resist the temptation to leave.

Acknowledgments. We wish to thank Andrew M. Colman, Jana Jarecki, Thomas Kessler, Oliver Kirchkamp, Franz Josef Neyer, Alena Otto, Luis Pedro Santos Pinto, Tobias Schmidt, Benedikt 
Werner, Sebastian Wilfling and two anonymous referees for references and suggestions.

\section{References}

Amato, P. R. AND B. Keith (1991): "Parental divorce and the well-being of children: a metaanalysis.” Psychological bulletin, 110, 26.

Ambrus, A. AND B. Greiner (2012): "Imperfect Public Monitoring with Costly Punishment: An Experimental Study," American Economic Review, 102, 3317-3332.

Aoyagi, M. AND G. FrÉChetTe (2009): "Collusion as public monitoring becomes noisy: Experimental evidence,” Journal of Economic Theory, 144, 1135-1165.

BARDSLey, N. AND R. SAUSGRUBer (2005): "Conformity and reciprocity in public good provision," Journal of Economic Psychology, 26, 664-681.

Bereby-Meyer, Y. AND A. E. Roth (2006): "The Speed of Learning in Noisy Games: Partial Reinforcement and the Sustainability of Cooperation," American Economic Review, 96, 10291042 .

Blanco, M., D. Engelmann, A. K. Koch, And H.-T. Normann (2010): "Belief elicitation in experiments: is there a hedging problem?" Experimental Economics, 13, 412-438.

Bohnet, I., F. Greig, B. Herrmann, AND R. Zeckhauser (2008): "Betrayal aversion: Evidence from Brazil, China, Oman, Switzerland, Turkey and the United States," American Economic Review, 98, 294-310.

BRAVO, G. AND F. SQUAZZONI (2013): "Exit, punishment and rewards in commons dilemmas: an experimental study," PloS one, 8, e69871.

CASON, T. N. AND F. U. KHAN (1999): "A laboratory study of voluntary public goods provision with imperfect monitoring and communication," Journal of Development Economics, 58, 533-552.

Charness, G. AND M.-C. Villeval (2009): "Cooperation and competition in intergenerational experiments in the field and the laboratory," American Economic Review, 99, 956-978.

ChiAppori, P.-A., B. Fortin, AND G. LACroix (2002): "Marriage market, divorce legislation, and household labor supply," Journal of political Economy, 110, 37-72.

DICKINSON, D. L. (1998): “The voluntary contributions mechanism with uncertain group payoffs," Journal of Economic Behavior \& Organization, 35, 517 - 533.

Dong, X. Y. AND G. K. Dow (1993): "Does Free Exit Reduce Shirking in Production Teams?" Journal of Comparative Economics, 17, 472-484.

Fehr, E., U. Fischbacher, AND M. Kosfeld (2005): "Neuroeconomic Foundations of Trust and Social Preferences: Initial Evidence," American Economic Review, 2, 346-351.

FISCHBACHER, U. (2007): "z-Tree: Zurich toolbox for ready-made economic experiments," Experimental Economics, 10, 171-178.

Fischbacher, U. AND S. GÄChter (2010): "Social Preferences, Beliefs, and the Dynamics of Free Riding in Public Goods Experiments," The American Economic Review, 100, 541-556. 
Fischbacher, U., S. GÄChter, AND E. Fehr (2001): "Are people conditionally cooperative? Evidence from a public goods experiment," Economics Letters, 71, 397-404.

Frank, R. H., T. GILOVICH, AND D. T. REGAN (1993): "Does studying economics inhibit cooperation?" The Journal of Economic Perspectives, 7, 159-171.

Fujiwara-Greve, T. AND Y. Yasuda (2011): "Repeated Cooperation with Outside Options," Working Paper, Keio University and National Graduate Institute for Policy Studies (GRIPS), 1092359.

Gächter, S., B. HerrmanN, AND C. Thöni (2004): "Trust, voluntary cooperation, and socioeconomic background: Survey and experimental evidence," Journal of Economic Behavior and Organization, 55, 505-531.

GONZÁLEZ, L. AND T. K. VitTANEN (2009): "The effect of divorce laws on divorce rates in Europe," European Economic Review, 53, 127-138.

Grechenig, K., A. NiCKLisch, AND C. ThÖNI (2010): "Punishment despite reasonable doubt-a public goods experiment with sanctions under uncertainty,” Journal of Empirical Legal Studies, $7,847-867$.

Greiner, B. (2004): "An Online Recruitment System for Economic Experiments," in Forschung und wissenschaftliches Rechnen, GWDG-Bericht Nr. 63, ed. by K. Kremer and V. Macho, Gesellschaft für Wissenschaftliche Datenverarbeitung, Göttingen, 79-93.

HAYASHI, N. AND T. YAMAGISHI (1998): "Selective play: Choosing partners in an uncertain world," Personality and Social Psychology Review, 2, 276-289.

Hirschman, A. O. (1970): Exit, Voice and Loyalty: Responses to Decline in Firms, Organizations, and States, Harvard University Press.

Katz-Navon, T. Y. AND M. EREZ (2005): "When Collective- and Self-Efficacy Affect Team Performance The Role of Task Interdependence," Small Group Research, 36, 437-465.

KerR, N. L. AND C. M. Kaufman-Gilliland (1997): ““.... and besides, I probably couldn’t have made a difference anyway": Justification of Social Dilemma Defection via Perceived SelfInefficacy," Journal of Experimental Social Psychology, 33, 211-230.

Keser, C. And C. Montmarquette (2011): "Voluntary versus Enforced Team Effort," Games, 2, 277-301.

Keser, C. AND F. V. Winden (2000): "Conditional Cooperation and Voluntary Contributions to Public Goods," The Scandinavian Journal of Economics, 102, 23-39.

Kocher, M. G., P. Martinsson, D. Matzat, and C. Wollbrant (2015): "The role of beliefs, trust, and risk in contributions to a public good," Journal of Economic Psychology, 51, 236-244.

Kuhn, P. AND M. C. Villeval (2014): “Are Women More Attracted to Co-operation Than Men?" The Economic Journal.

LERNER, J. AND J. TIROLE (2005): “The scope of open source licensing," Journal of Law, Economics, and Organization, 21, 20-56. 
Levati, M. AND A. Morone (2013): "Voluntary Contributions with Risky and Uncertain Marginal Returns: The Importance of the Parameter Values," Journal of Public Economic Theory, 15, 736744.

LiN, J. Y. (1990): "Collectivization and China's Agricultural Crisis in 1959-1961," Journal of Political Economy, 98, 1228-1252.

LIST, J. A. (2004): "Young, Selfish And Male: Field Evidence Of Social Preferences," The Economic Journal, 114, 121-149.

MACLEOD, W. B. (1988): "Equity, efficiency and incentives in cooperative teams," in Advances in the economic analysis of participatory and labor-managed firms, ed. by D. C. Jones and J. Svejnar, JAI Press, vol. 3, 5-23.

(1993): "The Role of Exit Costs in the Theory of Cooperative Teams: A Theoretical Perspective," Journal of Comparative Economics, 17, 521-529.

MARWELl, G. AND R. E. Ames (1981): “Economists free ride, does anyone else?” Journal of Public Economics, 15, 295-310.

Mulder, L. B., E. v. DiJK, D. D. Cremer, AND H. A. Wilke (2006): "Undermining trust and cooperation: The paradox of sanctioning systems in social dilemmas," Journal of Experimental Social Psychology, 42, 147-162.

MY, K. B. AND B. ChalvignaC (2010): "Voluntary participation and cooperation in a collectivegood game,” Journal of Economic Psychology, 31, 705-718.

Neugebauer, T., J. Perote, U. Schmidt, And M. Loos (2009): "Selfish-biased conditional cooperation: On the decline of contributions in repeated public goods experiments," Journal of Economic Psychology, 30, 52-60.

Orbell, J. M., P. Schwartz-Shea, And R. T. Simmons (1984): "Do Cooperators Exit More Readily than Defectors?” The American Political Science Review, 78, 147-162.

PAlfrey, T. AND J. PRisbrey (1996): "Altruism, reputation and noise in linear public goods experiments," Journal of Public Economics, 61, 409-427.

Palfrey, T. R. AND J. E. Prisbrey (1997): "Anomalous Behavior in Public Goods Experiments: How Much and Why?" American Economic Review, 87, 829-846.

Putterman, L. AND G. L. Skillman (1992): "The role of exit costs in the theory of cooperative teams," Journal of Comparative Economics, 16, 596-618.

RAnd, D. G., S. Arbesman, AND N. A. Christakis (2011): "Dynamic social networks promote cooperation in experiments with humans," Proceedings of the National Academy of Sciences, 108, 19193-19198, pMID: 22084103.

Stewart, K. J., A. P. Ammeter, And L. M. Maruping (2006): "Impacts of license choice and organizational sponsorship on user interest and development activity in open source software projects," Information Systems Research, 17, 126-144.

Tenbrunsel, A. E. And D. M. Messick (1999): "Sanctioning Systems, Decision Frames, and Cooperation," Administrative Science Quarterly, 44, 684-707. 
VAn DiJK, E., A. Wit, H. Wilke, AND D. Budescu (2004): "What we know (and do not know) about the effects of uncertainty on behavior in social dilemmas," in Contemporary psychological research on social dilemmas, ed. by R. Suleiman, D. V. Budescu, I. Fischer, and D. M. Messick, Cambridge University Press, 315-331.

VAn Lange, P. A., J. Joireman, C. D. PARKs, AND E. VAn DiJK (2013): "The psychology of social dilemmas: A review," Organizational Behavior and Human Decision Processes, 120, 125-141.

Wilson, A. J. AND H. WU (2014): "At-will Relationships: How An Option To Walk Away Affects Cooperation And Efficiency," Working Paper, University of Pittsburgh.

XiaO, E. AND H. KunReuther (2012): "Punishment and cooperation in stochastic social dilemmas,” Tech. Rep. No. 18458, National Bureau of Economic Research.

YAMAGISHI, T. (1988): "Exit from the group as an individualistic solution to the free rider problem in the United States and Japan," Journal of Experimental Social Psychology, 24, 530-542. 


\section{A. Supplementary Material - part 1}

\section{A.1. Socially optimal effort levels}

Suppose both agents participate in the public project. Total expected welfare generated by the joint project is $f\left(e_{i t}+e_{j t}\right)\left(v_{i}+v_{j}\right)-e_{i t}-e_{j t}$. Maximum social welfare when both agents are involved in the public project is then $f\left(e^{*}\right)\left(v_{i}+v_{j}\right)-e^{*}$, where $e^{*}=e_{i t}+e_{j t}$ is determined by the first order condition of the maximization problem, $f^{\prime}\left(e^{*}\right)\left(v_{i}+v_{j}\right)=1$. Suppose now both agents develop individually. In that case, total expected welfare generated by the two individual projects is $f\left(x_{l}+e_{i t}\right) v_{i}+f\left(x_{l}+e_{j t}\right) v_{j}-e_{i t}-e_{j t}$. Agent $i$ chooses effort $e_{i}^{*}$ such that $f^{\prime}\left(x_{l}+e_{i}^{*}\right) v_{i}=1$ while $j$ chooses effort $e_{j}^{*}$ such that $f^{\prime}\left(x_{l}+e_{j}^{*}\right) v_{j}=1$. Social welfare when both agents are involved in individual projects is then $f\left(x_{l}+e_{i}^{*}\right) v_{i}-e_{i}^{*}+f\left(x_{l}+e_{j}^{*}\right) v_{j}-e_{j}^{*}$. Given $f(z)=\sqrt{z / 22}$ as in the experiment, we find that maximum expected welfare in joint work is higher than maximum expected welfare in individual work for any $x_{l}<4.54$ when $v_{i}=v_{j}=20$ (symmetric case).

\section{A.2. Nash equilibrium}

We determine the Nash equilibrium for the one-shot version of a public good game with outside options when agents are risk-neutral.

\section{Effort}

Agent $i$ is paired with agent $j$ and such that $v_{i} \geq v_{j}$. Suppose both subject are active in the public project in period $t$. $i$ will maximize her own expected payoff $f\left(e p_{i t}+e p_{j t}^{e}\right) v_{i}-e p_{i t} . f(\cdot)$ is strictly concave so the first order condition for the maximization of this function is $f^{\prime}\left(e p_{i t}+e p_{j t}^{e}\right) v_{i}=1$ and there is only one value, which we denote $z_{i}$, such that that $f^{\prime}\left(z_{i}\right) v_{i}=1$. Since $f^{\prime}(\cdot)$ is decreasing in its argument, $z_{i}$ will be an increasing function of $v_{i}$. We obtain $z_{i}=v_{i}^{2} / 88$ for the case $f(z)=\sqrt{z / 22}$ as in the experiment. Probability of success is then $f\left(z_{i}\right)=v_{i} / 44$.

The best response function $e p_{i t}\left(e p_{j t}^{e}\right)=\max \left[z_{i}-e p_{j t}^{e}, 0\right]$ determines the optimal choice $e p_{i t}$ by $i$ for every expected level of effort of $j$. Given that $f^{\prime}(\cdot)$ is decreasing in its argument, $z_{i}$ will be higher than $z_{j}$ whenever $v_{i}>v_{j}$. The Nash equilibrium $\left(e p_{i t}^{*}, e p_{j t}^{*}\right)$ is such that each player's effort is a best-response to the other player's effort, that is, $e p_{i t}^{*}=\max \left[z_{i}-e p_{j t}^{*}, 0\right]$ and $e p_{j t}^{*}=\max \left[z_{j}-e p_{i t}^{*}, 0\right]$.

- If $v_{i}>v_{j}$ then $z_{i}>z_{j}$ and the Nash equilibrium is such that $e p_{i t}=z_{i}$ and $e p_{j t}=0$.

- If $v_{i}=v_{j}$ then any combination of efforts such that $e p_{i t}^{*}=z_{i}-e p_{j t}^{*}$ with $e p_{i t}^{*} \geq 0$ is a Nash equilibrium.

Similarly, the optimal level of effort in the individual project is $e i_{i t}^{*}=\max \left[z_{i}-x_{l}, 0\right]$ for treatments 2,3 and 4. In treatment 1 , the optimal level of effort is $e i_{i t}^{*}=0$. Finally, optimal level of effort in the public project alone is $e p a_{i t}^{*}=z_{i}$.

We summarize the Nash predictions for effort in table A.7.

Table A.7: Effort under the Nash equilibrium, by treatment.

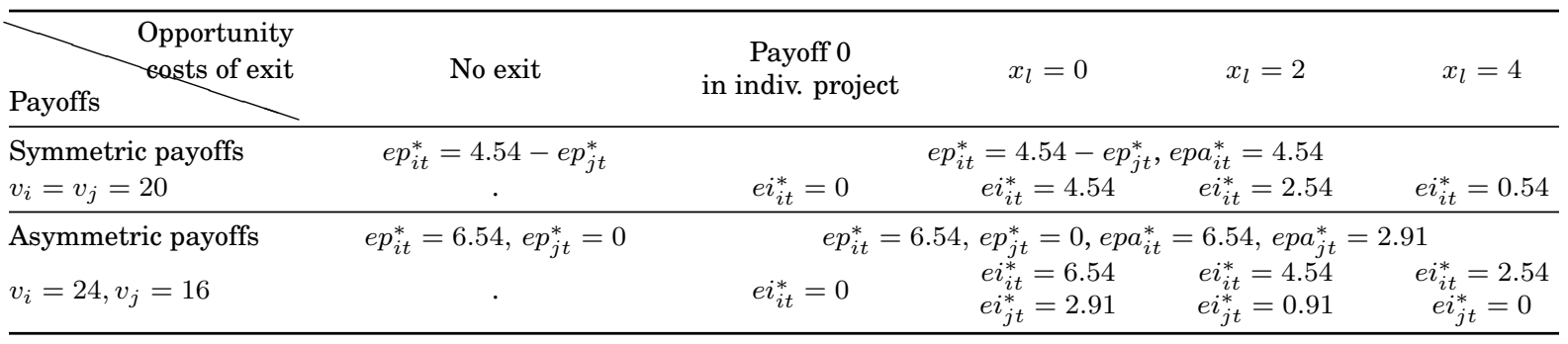




\section{Participation decision}

The decision $d_{i t}$ whether to participate in the public project depends on how expected payoff when staying compares with payoff in an individual project. In treatment 1 , it is never optimal to exit, so $d_{i t}^{*}=1$. In treatments 2,3 and 4 , we obtain $d_{i t}=1$ (participate in the public project) if:

$$
\left(1-d_{j t}^{e}\right) \times\left(f\left(e p a_{i t}\right) v_{i}-e p a_{i t}\right)+d_{j t}^{e} \times\left(f\left(e p_{i t}+e p_{j t}^{e}\right) v_{i}-e p_{i t}\right)>f\left(e i_{i t}+x_{l}\right) v_{i}-e i_{i t}
$$

This can be rewritten given equilibrium levels of effort for individual $i$ with $v_{i} \geq v_{j}$ :

$$
\left(1-d_{j t}^{e}\right) \times\left(f\left(z_{i}\right) v_{i}-z_{i}\right)+d_{j t}^{e} \times\left(f\left(z_{i}\right) v_{i}-z_{i}+e p_{j t}^{e}\right)>f\left(z_{i}\right) v_{i}-z_{i}+x_{l}
$$

Simplifying, subject $i$ with $v_{i} \geq v_{j}$ stays if expected opportunity cost of exit is more than zero:

$$
\underbrace{d_{j t}^{e} \times e p_{j t}^{e}-x_{l}}_{\text {expected opportunity cost of exit }}>0
$$

In words, subject $i$ with $v_{i} \geq v_{j}$ chooses the public project as long as the expected effort of her peer times the probability he chooses the public project is more than the subsidy to individual projects. The expression is different for individual $j$ with $v_{j}<v_{i}$, as that individual exerts no effort in the public project.

\section{Beliefs}

- In the symmetric case $\left(v_{i}=v_{j}\right)$, any belief $e p_{j t}^{e} \in\left[0, z_{i}\right]$ can be sustained in a Nash equilibrium. A subject will decide to choose the individual or the public project as a function of his beliefs $e p_{j t}^{e}$ and $d_{j t}^{e}$.

- In the asymmetric case $\left(v_{i}>v_{j}\right)$, then the only belief that can be sustained by $i$ in equilibrium is that $e p_{j t}^{e}=0$. Therefore subject $i$ is indifferent between exiting and staying in treatment 1 and will exit in treatments 3 and 4 . Subject $j$ with $v_{j}<v_{i}$ will have belief $e p_{i t}^{e}=z_{i}$ and will choose the individual project if $d_{i t}^{e}\left(z_{j}+f\left(z_{i}\right) v_{j}-f\left(z_{j}\right) v_{j}\right)<x_{l}$. However, the only reasonable belief $d_{i t}^{e}$ in treatments 3 and 4 is that $d_{i t}^{e}=0$. Therefore subject $j$ will choose the individual project for treatments 3 and 4 as well.

\begin{tabular}{|c|c|c|c|c|c|}
\hline \begin{tabular}{|c|c|c|} 
Opportunity \\
costs of exit
\end{tabular} & No exit & $\begin{array}{c}\text { Payoff } 0 \\
\text { in indiv. project }\end{array}$ & $x_{l}=0$ & $x_{l}=2$ & $x_{l}=4$ \\
\hline $\begin{array}{l}\text { Symmetric payoffs } \\
v_{i}=v_{j}=20\end{array}$ & . & $\begin{array}{l}d_{i t}=1 \\
d_{j t}=1\end{array}$ & $\begin{aligned} d_{i t} & =1 \\
d_{j t} & =1\end{aligned}$ & $\begin{array}{l}\times e p_{j t}^{e}>x_{l} \\
\times e p_{i t}^{e}>x_{l}\end{array}$ & \\
\hline $\begin{array}{l}\text { Asymmetric payoffs } \\
v_{i}=24, v_{j}=16\end{array}$ & . & $\begin{array}{l}d_{i t}=1 \\
d_{j t}=1\end{array}$ & $\begin{array}{c}d_{i t} \in[0,1] \\
d_{j t}=1 \text { if } d_{i t}^{e}>0\end{array}$ & $\begin{array}{l}d_{i t}=0 \\
d_{j t}=0\end{array}$ & $\begin{aligned} d_{i t} & =0 \\
d_{j t} & =0\end{aligned}$ \\
\hline
\end{tabular}

We summarize the Nash predictions for project selection in Table A.8.

Table A.8: Project selection under the Nash equilibrium, by treatment. 
Table A.9: Description of variables

\begin{tabular}{|c|c|}
\hline NAME & DESCRIPTION \\
\hline$i, j, k, l, m$ & $\begin{array}{l}\text { individual } i \text {, partner } j \text { of } i \text {, partnership } k \text { composed of } i \text { and } j \text {, treatment } l \text { to which } i \text { as } \\
\text { assigned, phase } m \text { of the experiment, }=1,2,3 \text { depending on whether } j \text { is } i \text { 's first, second or } \\
\text { third partner. }\end{array}$ \\
\hline$d_{i t}$ & participation decision by individual $i$ at time $t,=0$ if in individual project, 1 else. \\
\hline$d_{j t}$ & participation decision by partner $j$ of $i$ at time $t,=0$ if in individual project, 1 else. \\
\hline$d_{j t}^{e}$ & $\begin{array}{l}\text { individual } i \text { s expectation about the participation decision his partner } j \text {, in terms of proba- } \\
\text { bility of his being in the public project. }\end{array}$ \\
\hline$e p_{i t}$ & effort in public project by individual $i$ at time $t$. \\
\hline$e p_{j t}$ & effort in public project by partner $j$ of $i$ at time $t$. \\
\hline$e p_{j t}^{e}$ & $\begin{array}{l}\text { individual } i \text { 's expectation about the effort in the public project of partner } j \text { at time } t \text {. This is } \\
\text { observed only if } d_{i t}=d_{j t}=1 \text {. }\end{array}$ \\
\hline$e i_{i t}$ & effort in individual project by individual $i$ at time $t$. \\
\hline$e p a_{i t}$ & effort in public project by individual $i$ at time $t$ when alone (i.e. when $d_{i t}=1$ and $d_{j t}=0$ ). \\
\hline$e_{i t}-e_{j t}^{e}$ & $\begin{array}{l}\text { difference between one's own effort in one's chosen project and the expected effort of the } \\
\text { partner in his own chosen project. }\end{array}$ \\
\hline$s p_{i t}$ & $\begin{array}{l}\text { variable indicating success in the public project, }=-1 \text { if failure, }=1 \text { if success, }=0 \text { if there } \\
\text { is no public project. }\end{array}$ \\
\hline$s i_{i t}$ & $\begin{array}{l}\text { variable indicating success in the individual project, }=-1 \text { if failure, }=1 \text { if success, }=0 \text { if } \\
\text { the subject is not in an individual project. }\end{array}$ \\
\hline $\operatorname{spa}_{i t}$ & $\begin{array}{l}\text { variable indicating success in the public project when alone, }=-1 \text { if failure, }=1 \text { if success, } \\
=0 \text { if the subject is not alone in the public project.. }\end{array}$ \\
\hline$P_{i}$ & Vector of personal characteristics of $i$ \\
\hline$x_{l}$ & $\begin{array}{l}\text { value of the subsidy to the individual project for the treatment } l \text { to which } i \text { was assigned. } x_{l} \\
\text { is undefined for treatments } 0 \text { and } 1 \text {. }\end{array}$ \\
\hline treatment $l_{i}$ & $\begin{array}{l}\text { dummy variables indicating the treatment to which } i \text { was assigned, }=1 \text { if } i \text { was assigned to } \\
\text { treatment } l,=0 \text { else, } l=\{0, \ldots, 4\} \text {, e.g. treatment } 1_{i}=1 \text { if } i \text { was assigned to treatment } 1,0 \\
\text { else. }\end{array}$ \\
\hline$v_{i}$ & value received on successful completion of the project for $i$. \\
\hline female $_{i}$ & $=1$ if female, 0 else \\
\hline$a_{g e}$ & age of individual $i$ \\
\hline economist $_{i}$ & $\begin{array}{l}\text { Dummy variable equal to } 1 \text { for subjects studying business administration or economics, } 0 \\
\text { else. }\end{array}$ \\
\hline$r a_{i}$ & $\begin{array}{l}\text { index of risk aversion, taking value from } 0 \text { (most risk loving) to } 10 \text { (most risk averse). See } \\
\text { Section B.2. }\end{array}$ \\
\hline$s u_{i}$ & $\begin{array}{l}\text { index of aversion to strategic uncertainty, taking value from } 0 \text { (most uncertainty loving) to } \\
10 \text { (most averse to strategic uncertainty). See Section B.2. }\end{array}$ \\
\hline svo $_{i}$ & index of social value orientation, see Section B.2. \\
\hline & ex of trustfulnes \\
\hline$T_{t}$ & Vector of time varying characteristics \\
\hline start $_{t}$ & $\begin{array}{l}\text { Dummy variable }=1 \text { if period } t \text { is the start of a new partnership, } 0 \text { else. } \text { start }_{t}=1 \text { for } \\
t=\{1,9,23\}, 0 \text { else. }\end{array}$ \\
\hline pert & $\begin{array}{l}\text { Period within the partnership, }=1 \text { at the start of a partnership, }=2 \text { in the second period, } \\
\text { and so on. }\end{array}$ \\
\hline phase $_{m t}$ & $\begin{array}{l}\text { Dummy variable }=1 \text { if at period } t \text { the subject is in the } m^{t h} \text { phase, } m=\{1,2,3\} \text {, e.g. } \\
\text { phase } 1 t^{t}=1 \text { for } t \in[1,8], 0 \text { else. }\end{array}$ \\
\hline
\end{tabular}




\section{A.4. Estimation procedure}

\section{Estimating expected effort}

An issue given our belief elicitation mechanism is that we do not know $e p_{j t}^{e}$ if at time $t$ either subject was not in the public project $\left(d_{i t}=0\right.$ and/or $\left.d_{j t}=0\right)$. We therefore need to reconstruct $e p_{j t}^{e}$ for those missing periods. Beliefs about the effort the peer exerts or would exert in the public project will be assumed to follow a dynamic process for $t>1$ :

$$
e p_{j t}^{e}=\alpha+\rho \times e p_{j t-1}^{e}+\beta \times s p_{i t-1}+p \times P_{i}+c \times s t a r t_{t}+u_{i}+\epsilon_{i t}
$$

with $\rho<1$. Initial expectations $e p_{j 0}^{e}$ will be taken to be equal to the first elicited beliefs about effort of the peer. Since subjects most often started out in a public project, this is usually beliefs in period 1. Beliefs evolve depending on whether the public project was successful last period $\left(s p_{i t-1}=1\right)$, unsuccessful $\left(s p_{i t-1}=-1\right)$ or did not take place $\left(s p_{i t}=0\right)$. We expect that $\beta$ will be positive (a success is a good signal about the effort of the peer, assuming of course that success will not lead the peer to decrease his effort next period). Expectations are carried over from phase to phase with possibly adjustments upwards or downwards with the start of a new phase $\left(\right.$ start $\left._{t}\right)$, which is reflected in parameters $c$ in equation A.4. Expectations also depend on personal characteristics, including the value of the project to the peer $\left(v_{i}\right.$ is a proxy for $v_{j}$ as $\left.v_{j}=40-v_{i}\right)$. Subjects ought to think that those with lower value for the project will contribute less, so the parameter on $v_{i}$ should be negative.

Included in our regression are all observations for which $e p_{j t}^{e}$ and $e p_{j t-1}^{e}$ were observed, so our selection variable is selection $n_{i t}=1$ if $d_{i t}=d_{i t-1}=1$ and $d_{j t}=d_{j t-1}=1,0$ else. We assume selection depends on the following variables:

$$
\text { selection }_{i t}=1\left[\alpha+\gamma \times d_{j t}^{e}+\delta \times s p_{i t-1}+p \times P_{i}+c \times\left(\text { phase }_{m t}, \text { per }_{t}\right)+u_{i}+\epsilon_{i t}>0\right]
$$

with $\epsilon_{i t}$ distributed normally. Controls include $P_{i}$, a vector of personal characteristics, dummies phase $_{m t}$ for the phase in which subjects are (second or third pairing) and a variable taking for value the period within the pairing.

We start with estimates of equation A.4 by restricting $\rho$ to being equal to 1 , which gets rid of estimation issues with this auto-regressive term. The test for selection effect suggested in procedure 3.2 in Wooldridge (1995) is not significant (Inverse Mill Ratio ("IMR") parameter, column 1 of Table A.10) but corrected estimates as per procedure 4.2 in Wooldridge (1995) show that the null of no selection bias is rejected at the $5 \%$ level as the $I M R_{t}$, obtained from estimating equation A. 5 for each period separately across all individuals, are jointly significant (Wald test) (column 2 of Table A.10). Unlike Wooldridge (1995) we include the mean $\bar{x}_{i}$ of time-varying variables $x_{i t}$ in the regressions along $x_{i t}$ rather than the full vector $\left(x_{i 1}, x_{i 2}, \ldots, x_{i 32}\right)$. This is because there are too many periods for too few individuals to be able to estimate that many parameters reliably.

In a second step, we let $\rho$ be a free parameter and apply a first difference instrumental variables estimator along procedure 3 in Semykina and Wooldridge (2013) (columns 3 and 4 of Table A.10). This consists in estimating equation A.4 in differences while correcting for sample selection in the same way as in Wooldridge (1995) and using $e p_{j t-2}^{e}$ as an instrument for $\Delta e p_{j t-1}^{e}$ as suggested in Anderson and Hsiao (1981). In that case, the selection variable is selection ${ }_{i t}=1$ if $d_{i t}=d_{i t-1}=$ $d_{i t-2}=1$ and $d_{j t}=d_{j t-1}=d_{j t-2}=1,0$ else, as we need to observe $e p_{j t-2}^{e}$, our instrument. The selection equation is as in equation A.5. We find here that the $I M R_{t}$ are not jointly significant (Wald test). 
Finally, we apply the NLS estimator as per procedure 1 in Semykina and Wooldridge (2013), whereby we estimate the following equation for $t>1$ :

$$
\begin{aligned}
e p_{j t}^{e}= & \rho^{t-1} \times e p_{j 0}^{e}+\beta \times \sum_{j=1}^{t-1} \rho^{j-1} \times s p_{i t-j}+\frac{1-\rho^{t-1}}{1-\rho} \times\left(\alpha+p \times P_{i}+\gamma \times e p_{j 0}^{e}\right)+\ldots \\
& \ldots+c \times \sum_{j=1}^{t-1} \rho^{j-1} \times \text { start }_{t-j}+\varphi_{t} \times I M R_{i t}+\epsilon_{i t 2}
\end{aligned}
$$

The selection variable is now selection $i t=1$ if $d_{i t}=1$ and $d_{j t}=1,0$ else. $I M R_{i t}$ is the inverse Mills ratio obtained from estimating equation A.5 in period $t$ for each individual $i$.

Results are shown in columns 5 and 6 of Table A.10. We find that the IMRs are jointly significant. We test the results for robustness by breaking down the regression by treatment (Table A.11). Results are consistent across treatments except that success last period in the public project does not appear to impact expected effort in treatment 4 . We also ran the same regressions using dummies for different values of $v$. We still found no effect.

All standard errors are obtained through "panel bootstrap", which "involves re-sampling crosssectional units (and all time periods for each unit sampled) and using the bootstrap sample to approximate the distribution of the parameter vector" (Semykina and Wooldridge, 2010). Bootstrapping is "an alternative method for estimating the standard errors when the theoretical calculation is complicated" (Guan, 2003). Panel bootstrap obtains a consistent variance-covariance matrix of the estimators in the presence of heteroskedasticity and serial correlation for $N \rightarrow \infty$ and $T$ fixed.

\section{Estimates for the decision to take part in the public project}

Based on the results of the estimation of $e p_{j t}^{e}$ from equation A.6, we obtain reconstructed beliefs $e \hat{p}_{j t}^{e}$. We then use those reconstructed beliefs to estimate the following reduced form selection equation for treatment $t_{i} \geq 1$ :

$$
\begin{aligned}
d_{i t}= & 1\left[\alpha+\lambda \times\left(d_{j t}^{e} \times e \hat{p}_{j t}^{e}-x_{l}\right)+\pi \times s p_{i t-1}+\ldots\right. \\
& \ldots+\delta \times\left(e p_{i t-1}-e p_{j t-1}^{e}\right)+\theta \times d_{j t}^{e}+\ldots \\
& \left.\ldots+p \times P_{i}+c \times\left(\text { phase }_{m t}, \text { per }_{t}\right)+u_{i}+\epsilon_{i t}>0\right]
\end{aligned}
$$

Since $x_{i}$ is not defined for treatment 1 , we set it equal to 0 for the purpose of this regression. Parameters in the decision equation can be estimated with a conditional fixed-effects logit model. According to equation 1, the decision to exit in treatments 2, 3 and 4 depends on whether the cross term $d_{j t}^{e} \times e \hat{p}_{j t}^{e}$ exceeds the subsidy to individual projects $x_{l}$. The probability to participate in the public project also depends on the expected participation decision of the peer $\left(d_{j t}^{e}\right)$, on success or failure last period in the public project, $s p_{i t-1}$ and on variable $\left(e p_{i t-1}-e p_{j t-1}^{e}\right)$ which is the difference between one's effort and effort expected from one's partner.

Results are shown in Table 5, first with a pooled OLS regression, as before with bootstrapped standard errors for the parameter estimates (column 1). There is significant auto-correlation in the idiosyncratic error of our model, so we specify AR(1) within-panel error correlation structure in a population-averaged model (column 2). The column 3 shows results for a fixed-effect model, and column 4 for a random-effects model. A Hausman test rejects the hypothesis that the individuallevel effects are adequately modeled by a random-effects model. We also ran the same regressions 
using dummies for different values of $v$. We still found no effect. Regressions by treatments are shown in Tables 6.

\section{Effort in the public project}

Effort in the public project is assumed to evolve according to the following equation:

$$
e p_{i t}=\alpha+\sigma \times e p_{j t}^{e}+\phi \times s p_{i t-1}+\tau \times\left(1-d_{j t-1}\right)+p \times P_{i}+c \times\left(\text { phase }_{m t}, \text { per }_{t}\right)+u_{i}+\epsilon_{i t}
$$

so that effort depends on the expected effort of the peer. Experiments on the public good game show that $\sigma$ in this setting is positive - conditional cooperation -, but temptation to free-ride might be greater in an environment where the outcome is stochastic so the partner's effort is not observable. We consider also the direct effect of success in the previous period $s p_{i t-1}$. Indeed, while a rational agent would vary his effort only as a function of his beliefs about the effort of their partner, success (or failure) may also have a psychological effect, such that for example a subject may want to "compensate" failure in the previous period by increasing effort and vice-versa. We also include $1-d_{j t-1}$ to determine if one's partner returning to the public project had a positive effect on effort levels within the public project, as ought to be the case if punishment by leaving the public project is meant to have an incentive effect rather than being a purely punitive action. The selection variable is selection $_{i t}=1$ if $d_{i t}=1$ and $d_{j t}=1,0$ else, as this determines whether $e p_{i t}$ is observed. We include all regressors of equation A.7 in the selection equation. Results for fixed effect panel regressions are shown in Table A.12. The test for selection effect suggested in procedure 3.2 in Wooldridge (1995) is not significant at the 5\% level (Inverse Mill Ratio ("IMR") parameter). Corrected estimates as per procedure 4.2 in Wooldridge (1995) are very similar. Using dummies for different values of $v$ rather than using $v$ as a regressor does not impact the result. 
Table A.10: Table of regression results for $e p_{j t}^{e}$

\begin{tabular}{|c|c|c|c|c|c|c|}
\hline $\begin{array}{l}\text { dependent } \\
\text { variable }\end{array}$ & $\begin{array}{c}\text { 1. FE TEST } \\
\text { selection } \\
\text { effect } \\
e p_{j t}^{e} \\
\end{array}$ & $\begin{array}{l}\text { 2. POOLED OLS } \\
\text { w/ selection } \\
\text { correction } \\
e p_{j t}^{e}\end{array}$ & $\begin{array}{c}\text { 3. FD-IV } \\
\text { w/o selection } \\
\text { correction } \\
e p_{j t}^{e} \\
\end{array}$ & $\begin{array}{c}\text { 4. FD-IV } \\
\text { w/ selection } \\
\text { correction } \\
e p_{j t}^{e} \\
\end{array}$ & $\begin{array}{c}5 . \text { NLS } \\
\text { w/o selection } \\
\text { correction } \\
e p_{j t}^{e} \\
\end{array}$ & $\begin{array}{c}6 . \text { NLS } \\
\text { w/ selection } \\
\text { correction } \\
e p_{j t}^{e} \\
\end{array}$ \\
\hline$e p_{j t-1}^{e}$ & 1 & 1 & $\begin{array}{l}0.2664 * * * \\
(5.54)\end{array}$ & $\begin{array}{l}0.2601 * * * \\
(4.69)\end{array}$ & $\begin{array}{l}0.8098 * * * \\
(28.34)\end{array}$ & $\begin{array}{l}0.8099 \text { ** } \\
(28.26)\end{array}$ \\
\hline$s p_{i t-1}$ & $\begin{array}{l}0.2315 * * * \\
(6.43)\end{array}$ & $\begin{array}{l}0.2276 * * * \\
(6.18)\end{array}$ & $\begin{array}{l}0.1501 * * * \\
(4.94)\end{array}$ & $\begin{array}{l}0.1744 * * * \\
(5.26)\end{array}$ & $\begin{array}{l}0.3534 * * * \\
(8.91)\end{array}$ & $\begin{array}{l}0.3712 * * * \\
(8.14)\end{array}$ \\
\hline start $_{t}$ & $\begin{array}{l}0.1907 * \\
(2.39)\end{array}$ & $\begin{array}{l}0.2324 * \\
(2.20)\end{array}$ & $\begin{array}{l}0.1873 * \\
(2.44)\end{array}$ & $\begin{array}{l}0.2559 * * \\
(3.21)\end{array}$ & $\begin{array}{l}0.1200 \\
(1.56)\end{array}$ & $\begin{array}{c}0.0369 \\
(0.44)\end{array}$ \\
\hline$v$ & & $\begin{array}{l}0.0011 \\
(0.41)\end{array}$ & & & $\begin{array}{l}0.0121 \\
(1.51)\end{array}$ & $\begin{array}{l}0.0123 \\
(1.55)\end{array}$ \\
\hline treatment 1 & & $\begin{array}{l}-0.0080 \\
(-0.44)\end{array}$ & & & $\begin{array}{l}0.0657 \\
(1.15)\end{array}$ & $\begin{array}{l}0.0617 \\
(1.14)\end{array}$ \\
\hline treatment 2 & & $\begin{array}{l}-0.0497+ \\
(-1.89)\end{array}$ & & & $\begin{array}{l}-0.0041 \\
(-0.08)\end{array}$ & $\begin{array}{l}-0.0234 \\
(-0.42)\end{array}$ \\
\hline treatment 3 & & $\begin{array}{l}-0.0211 \\
(-0.65)\end{array}$ & & & $\begin{array}{l}0.0639 \\
(0.96)\end{array}$ & $\begin{array}{l}0.0245 \\
(0.35)\end{array}$ \\
\hline treatment 4 & & $\begin{array}{l}0.0157 \\
(0.24)\end{array}$ & & & $\begin{array}{l}0.1737 * \\
(2.31)\end{array}$ & $\begin{array}{l}0.1002 \\
(1.32)\end{array}$ \\
\hline female & & $\begin{array}{l}-0.0019 \\
(-0.13)\end{array}$ & & & $\begin{array}{l}-0.0416 \\
(-0.95)\end{array}$ & $\begin{array}{l}-0.0481 \\
(-1.06)\end{array}$ \\
\hline age & & $\begin{array}{l}-0.0016 \\
(-0.95)\end{array}$ & & & $\begin{array}{l}-0.0039 \\
(-1.02)\end{array}$ & $\begin{array}{l}-0.0042 \\
(-0.98)\end{array}$ \\
\hline economist & & $\begin{array}{l}0.0228 \\
(0.85)\end{array}$ & & & $\begin{array}{l}-0.0255 \\
(-0.38)\end{array}$ & $\begin{array}{l}-0.0260 \\
(-0.40)\end{array}$ \\
\hline$r a$ & & $\begin{array}{l}-0.0008 \\
(-0.16)\end{array}$ & & & $\begin{array}{l}0.0032 \\
(0.20)\end{array}$ & $\begin{array}{c}0.0037 \\
(0.24)\end{array}$ \\
\hline su & & $\begin{array}{l}-0.0021 \\
(-0.76)\end{array}$ & & & $\begin{array}{l}0.0005 \\
(0.06)\end{array}$ & $\begin{array}{l}0.0002 \\
(0.02)\end{array}$ \\
\hline svo & & $\begin{array}{l}0.0092 \\
(0.28)\end{array}$ & & & $\begin{array}{l}0.0275 \\
(0.35)\end{array}$ & $\begin{array}{l}0.0334 \\
(0.37)\end{array}$ \\
\hline trustful & & $\begin{array}{l}-0.0042 \\
(-0.67)\end{array}$ & & & $\begin{array}{l}-0.0313+ \\
(-1.74)\end{array}$ & $\begin{array}{l}-0.0318+ \\
(-1.72)\end{array}$ \\
\hline$e p_{j 0}^{e}$ & & & & & $\begin{array}{l}0.0723 * * * \\
(3.87)\end{array}$ & $\begin{array}{l}0.0719 * * * \\
(4.25)\end{array}$ \\
\hline constant & & $\begin{array}{l}-0.1512 \\
(-1.51)\end{array}$ & & & $\begin{array}{l}0.3269 \\
(1.45)\end{array}$ & $\begin{array}{l}0.3362 \\
(1.58)\end{array}$ \\
\hline $\begin{array}{l}I M R \\
\chi^{2}\left(I M R_{t}\right)\end{array}$ & 0.1440 & $46 *$ & & 31 & & $54 * *$ \\
\hline$N$ & 6962 & 6962 & 6513 & 6495 & 7353 & 7353 \\
\hline Subjects & 281 & 281 & 275 & 274 & 294 & 294 \\
\hline$d f$ & 3 & 47 & 3 & 32 & 17 & 48 \\
\hline Wald test $\chi^{2}$ & $45 * * *$ & $125 * * *$ & $42 * * *$ & $78 * * *$ & $87152 * * *$ & $131850 * * *$ \\
\hline
\end{tabular}

$z$ statistics in parentheses, bootstrapped standard errors, 200 replications.

$+p<0.10,{ }^{*} p<0.05,{ }^{* *} p<0.01,{ }^{* * *} p<0.001$ 
Table A.11: Table of regression results for $e p_{j t}^{e}$, NLS by treatments

\begin{tabular}{|c|c|c|c|c|c|}
\hline \multirow[b]{2}{*}{ dep. variable } & \multicolumn{5}{|c|}{ NLS W/ SELECTION CORRECTION } \\
\hline & $\begin{array}{c}\text { TREATMENT } 0 \\
e p_{j t}^{e}\end{array}$ & $\begin{array}{c}\text { TREATMENT } 1 \\
e p_{j t}^{e}\end{array}$ & $\begin{array}{c}\text { TREATMENT } 2 \\
e p_{j t}^{e}\end{array}$ & $\begin{array}{c}\text { TREatMENT } 3 \\
e p_{j t}^{e}\end{array}$ & $\begin{array}{c}\text { TREATMENT } 4 \\
e p_{j t}^{e}\end{array}$ \\
\hline \multirow[t]{2}{*}{$e p_{j t-1}^{e}$} & $0.8068 * * *$ & $0.8137 * * *$ & $0.7779 * * *$ & $0.7715 * * *$ & $0.6756 * * *$ \\
\hline & (21.78) & $(5.41)$ & $(10.19)$ & $(6.04)$ & $(4.79)$ \\
\hline$s p_{i t-1}$ & $\begin{array}{l}0.4818 * * * \\
(6.62)\end{array}$ & $\begin{array}{l}0.2472 * * \\
(2.84)\end{array}$ & $\begin{array}{l}0.5274 * * * \\
(4.44)\end{array}$ & $\begin{array}{l}0.2866 * * \\
(3.07)\end{array}$ & $\begin{array}{l}0.1126 \\
(1.28)\end{array}$ \\
\hline \multirow[t]{2}{*}{ start $_{t}$} & 0.0307 & 0.0677 & 0.1042 & -0.0185 & 0.1523 \\
\hline & $(0.26)$ & $(0.46)$ & $(0.51)$ & $(-0.10)$ & $(0.38)$ \\
\hline \multirow[t]{2}{*}{$v$} & -0.0035 & 0.0276 & 0.0156 & 0.0212 & -0.0131 \\
\hline & $(-0.25)$ & $(0.70)$ & $(0.70)$ & $(0.63)$ & $(-0.39)$ \\
\hline \multirow[t]{2}{*}{ female } & -0.0439 & -0.2089 & -0.0328 & 0.0396 & 0.1287 \\
\hline & $(-0.57)$ & $(-1.00)$ & $(-0.25)$ & $(0.25)$ & $(0.68)$ \\
\hline \multirow[t]{2}{*}{ age } & -0.0171 & 0.0003 & -0.0028 & -0.0075 & 0.0074 \\
\hline & $(-1.32)$ & $(0.03)$ & $(-0.21)$ & $(-0.39)$ & $(0.26)$ \\
\hline economist & $\begin{array}{l}0.1832+ \\
(1.76)\end{array}$ & $\begin{array}{l}-0.2958 \\
(-1.07)\end{array}$ & $\begin{array}{l}-0.2084 \\
(-1.24)\end{array}$ & $\begin{array}{c}0.2204 \\
(0.87)\end{array}$ & $\begin{array}{l}0.1571 \\
(0.49)\end{array}$ \\
\hline \multirow[t]{2}{*}{$r a$} & -0.0262 & 0.0284 & 0.0093 & 0.0280 & $-0.1309+$ \\
\hline & $(-0.63)$ & $(0.55)$ & $(0.20)$ & $(0.56)$ & $(-1.65)$ \\
\hline \multirow[t]{2}{*}{$s u$} & -0.0083 & -0.0013 & 0.0107 & 0.0256 & -0.0211 \\
\hline & $(-0.41)$ & $(-0.05)$ & $(0.31)$ & $(0.68)$ & $(-0.46)$ \\
\hline \multirow[t]{2}{*}{ svo } & -0.1108 & 0.2171 & -0.1346 & 0.0440 & -0.1066 \\
\hline & $(-0.57)$ & $(0.97)$ & $(-0.55)$ & $(0.13)$ & $(-0.25)$ \\
\hline \multirow[t]{2}{*}{ trustful } & -0.0414 & 0.0064 & -0.0192 & -0.0806 & -0.0561 \\
\hline & $(-1.12)$ & $(0.15)$ & $(-0.32)$ & $(-1.34)$ & $(-0.73)$ \\
\hline \multirow[t]{2}{*}{$e p_{j 0}^{e}$} & 0.0373 & 0.0891 & $0.1024 *$ & 0.0827 & $0.1912+$ \\
\hline & $(1.14)$ & $(0.89)$ & $(2.29)$ & $(1.18)$ & $(1.80)$ \\
\hline \multirow[t]{2}{*}{ constant } & $1.3921 *$ & -0.1873 & 0.1064 & 0.1470 & 1.7710 \\
\hline & $(2.44)$ & $(-0.25)$ & $(0.19)$ & $(0.17)$ & (1.49) \\
\hline$\chi^{2}\left(I M R_{t}\right)$ & . & 11.83 & $44.02+$ & $43.03+$ & 37.85 \\
\hline$N$ & 1860 & 1942 & 1722 & 1251 & 578 \\
\hline Subjects & 60 & 64 & 64 & 59 & 47 \\
\hline$d f$ & 13 & 44 & 44 & 44 & 44 \\
\hline Wald test $\chi^{2}$ & $32878 * * *$ & $34345 * * *$ & $22575 * * *$ & $21578 * * *$ & $17206 * * *$ \\
\hline
\end{tabular}

$z$ statistics in parentheses, bootstrapped standard errors, 200 replications.

${ }^{+} p<0.10,{ }^{*} p<0.05,{ }^{* *} p<0.01,{ }^{* * *} p<0.001$

Table A.12: Tables of regression results for effort in common projects, fixed effect, with test for selection effect

\begin{tabular}{|c|c|c|c|c|c|c|}
\hline Dependent var. & $\begin{array}{l}\text { 1. ALL } \\
e p_{i t}\end{array}$ & $\begin{array}{l}\text { 2. TREATMENT } 03 . \\
e p_{i t}\end{array}$ & $\begin{array}{l}\text { TREATMENT } 14 . \\
e p_{i t}\end{array}$ & $\begin{array}{l}\text { TREATMENT } 25 . \\
e p_{i t}\end{array}$ & $\begin{array}{l}\text { TREATMENT } 36 . \\
e p_{i t}\end{array}$ & $\begin{array}{l}\text { TREATMENT } 4 \\
e p_{i t}\end{array}$ \\
\hline$e p_{j t}^{e}$ & $\begin{array}{l}0.1433 * * \\
(2.88)\end{array}$ & $\begin{array}{l}0.2009 * * \\
(2.95)\end{array}$ & $\begin{array}{l}-0.0178 \\
(-0.17)\end{array}$ & $\begin{array}{l}0.2509 * \\
(2.54)\end{array}$ & $\begin{array}{l}0.1113 \\
(1.64)\end{array}$ & $\begin{array}{l}0.0309 \\
(0.35)\end{array}$ \\
\hline$s p_{i t-1}$ & $\begin{array}{l}-0.0482 \\
(-1.41)\end{array}$ & $\begin{array}{l}-0.0435 \\
(-0.68)\end{array}$ & $\begin{array}{l}-0.0253 \\
(-0.38)\end{array}$ & $\begin{array}{l}-0.0732 \\
(-1.57)\end{array}$ & $\begin{array}{l}-0.0826 * \\
(-2.13)\end{array}$ & $\begin{array}{l}-0.0682 \\
(-1.16)\end{array}$ \\
\hline $1-d_{j t-1}$ & $\begin{array}{l}0.0197 \\
(0.17)\end{array}$ & . & $\begin{array}{l}-0.6218 \\
(-1.55)\end{array}$ & $\begin{array}{l}-0.0363 \\
(-0.17)\end{array}$ & $\begin{array}{l}0.3291+ \\
(1.67)\end{array}$ & $\begin{array}{l}-0.0059 \\
(-0.04)\end{array}$ \\
\hline per & $\begin{array}{l}-0.0248 * * \\
(-3.18)\end{array}$ & $\begin{array}{l}-0.0267 \\
(-1.46)\end{array}$ & $\begin{array}{l}-0.0311 * \\
(-2.14)\end{array}$ & $\begin{array}{l}-0.0232 \\
(-1.51)\end{array}$ & $\begin{array}{l}-0.0137 \\
(-1.44)\end{array}$ & $\begin{array}{l}-0.0203 \\
(-1.44)\end{array}$ \\
\hline phase 2 & $\begin{array}{l}-0.1345 \\
(-1.58)\end{array}$ & $\begin{array}{l}-0.0570 \\
(-0.38)\end{array}$ & $\begin{array}{l}-0.1828 \\
(-1.05)\end{array}$ & $\begin{array}{l}-0.2609 \\
(-1.55)\end{array}$ & $\begin{array}{l}-0.1348 \\
(-0.79)\end{array}$ & $\begin{array}{l}0.2836 \\
(1.39)\end{array}$ \\
\hline phase 3 & $\begin{array}{l}-0.1815+ \\
(-1.79)\end{array}$ & $\begin{array}{l}-0.1689 \\
(-0.91)\end{array}$ & $\begin{array}{l}-0.3064 \\
(-1.51)\end{array}$ & $\begin{array}{l}-0.2158 \\
(-1.10)\end{array}$ & $\begin{array}{l}-0.0278 \\
(-0.14)\end{array}$ & $\begin{array}{l}-0.0131 \\
(-0.06)\end{array}$ \\
\hline$I M R$ & $\begin{array}{l}0.1852+ \\
(1.73)\end{array}$ & . & $\begin{array}{l}0.8133+ \\
(1.71)\end{array}$ & $\begin{array}{l}0.1855 \\
(0.88)\end{array}$ & $\begin{array}{l}0.0950 \\
(0.48)\end{array}$ & $\begin{array}{l}0.0679 \\
(0.56)\end{array}$ \\
\hline constant & $\begin{array}{l}4.8122 * * * \\
(16.76)\end{array}$ & $\begin{array}{l}4.4802 * * * \\
(9.03)\end{array}$ & $\begin{array}{l}5.8796 * * * \\
(10.38)\end{array}$ & $\begin{array}{l}4.0996 * * * \\
(7.07)\end{array}$ & $\begin{array}{l}4.8634 * * * \\
(8.78)\end{array}$ & $\begin{array}{l}5.5693 * * * \\
(10.62)\end{array}$ \\
\hline$N$ & 7353 & 1860 & 1942 & 1722 & 1251 & 578 \\
\hline Subjects & 294 & 60 & 64 & 64 & 59 & 47 \\
\hline$d f$ & 7 & 5 & 7 & 7 & 7 & 7 \\
\hline Wald test $\chi^{2}$ & $29.25 * * *$ & $15.19 * *$ & $12.22+$ & $22.18 * *$ & $16.30+$ & 6.70 \\
\hline
\end{tabular}

$z$ statistics in parentheses, bootstrapped standard errors, 200 replications.

${ }^{+} p<0.10,{ }^{*} p<0.05,{ }^{* *} p<0.01,{ }^{* * *} p<0.001$ 


\section{B. Supplementary material - part 2}

\section{B.1. Instructions for treatment 3, asymmetric payoffs, payoff $=24$ \\ Translated from German instructions}

Welcome and thank you for your participation! You can earn money in this experiment, how much depends on your decisions and on the decisions of the other participants. It is therefore very important that you read these instructions thoroughly and completely.

Please note that you are not allowed to talk with other participants during the entire experiment. If you have a question, please raise your hand and we will then come to you and answer your question. We ask that you do not express your question(s) aloud before we come to you, and that you ask your question in a low voice so others cannot hear you. We will have to exclude you from the experiment if you violate these rules.

\section{Please ENSURE THAT YOUR MOBILE PHONE IS TURNED OFF NOW!}

\section{General procedure}

1. The experiment lasts about 110 minutes.

2. There will be three rounds in which you will keep performing the same tasks for a given number of periods.

3 . In each of the 3 rounds you will be paired with a different participant in this session (your peer). This person will not have been paired with you or with anyone you were paired with in previous rounds.

4. Each round is divided into periods. The number of periods in each round is determined by a random process, so that the round ends with probability $5 \%$ after each period.

5. One period will be selected randomly at the end of the experiment and will determine your earnings. Your earnings will be calculated in ECU (Experimental Currency Units). 1 ECU corresponds to $0.50 €$. At the end of today's session, your ECU earnings will be converted into euros and will be paid to you in cash.

6. You will receive $10 \mathrm{ECU}$ (equivalent to $5 €$ ) for participating. If you make losses in this experiment, those will be deducted from this payment. However, your total earnings are guaranteed never to be negative.

7. You will be asked to fill out a questionnaire before you receive your payment.

8. You will also be asked to take a few additional decisions unrelated to the main part of the experiment, for which you will be paid.

\section{Procedure in each period}

In each period you must make the decision whether to participate in project $\mathrm{K}$ or in project G1. Your peer is facing a choice as well whether to participate in project $\mathrm{K}$ or in project G2. These projects will be described in the following pages. After this decision, you and your peer determine how much you wish to invest in the project you selected.

\section{Suppose you participate in project $K$ and your peer participates in Project $K$ as well:}

If both you and your peer participate in Project K, then the probability of success of project $\mathrm{K}$ depends both on the investment of your peer as well as on your investment. You and your peer may invest any sum between 0 and 10 ECU each. The probability the project is successful increases with the sum of your investments according to the following formula:

Probability of success $=\sqrt{(\text { your investment+investment of your pair })} / \sqrt{22}$ 
The resulting probabilities can be seen in the table below (investments are shown only for whole numbers in the table, but you can choose investments between whole numbers). For a given investment by yourself (in columns), you can see how the likelihood of success for the project varies as a function of your peer's investment (in rows).

\begin{tabular}{|c|c|c|c|c|c|c|c|c|c|c|c|c|}
\hline & & \multicolumn{11}{|c|}{ Your investment } \\
\hline & & $\mathbf{0}$ & 1 & 2 & 3 & 4 & 5 & 6 & 7 & 8 & 9 & 10 \\
\hline \multirow{11}{*}{ 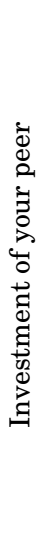 } & $\mathbf{0}$ & $0 \%$ & $21 \%$ & $30 \%$ & $37 \%$ & $43 \%$ & $48 \%$ & $52 \%$ & $56 \%$ & $60 \%$ & $64 \%$ & $67 \%$ \\
\hline & 1 & $21 \%$ & $30 \%$ & $37 \%$ & $43 \%$ & $48 \%$ & $52 \%$ & $56 \%$ & $60 \%$ & $64 \%$ & $67 \%$ & $71 \%$ \\
\hline & 2 & $30 \%$ & $37 \%$ & $43 \%$ & $48 \%$ & $52 \%$ & $56 \%$ & $60 \%$ & $64 \%$ & $67 \%$ & $71 \%$ & $74 \%$ \\
\hline & 3 & $37 \%$ & $43 \%$ & $48 \%$ & $52 \%$ & $56 \%$ & $60 \%$ & $64 \%$ & $67 \%$ & $71 \%$ & $74 \%$ & $77 \%$ \\
\hline & 4 & $43 \%$ & $48 \%$ & $52 \%$ & $56 \%$ & $60 \%$ & $64 \%$ & $67 \%$ & $71 \%$ & $74 \%$ & $77 \%$ & $80 \%$ \\
\hline & 5 & $48 \%$ & $52 \%$ & $56 \%$ & $60 \%$ & $64 \%$ & $67 \%$ & $71 \%$ & $74 \%$ & $77 \%$ & $80 \%$ & $83 \%$ \\
\hline & 6 & $52 \%$ & $56 \%$ & $60 \%$ & $64 \%$ & $67 \%$ & $71 \%$ & $74 \%$ & $77 \%$ & $80 \%$ & $83 \%$ & $85 \%$ \\
\hline & 7 & $56 \%$ & $60 \%$ & $64 \%$ & $67 \%$ & $71 \%$ & $74 \%$ & $77 \%$ & $80 \%$ & $83 \%$ & $85 \%$ & $88 \%$ \\
\hline & 8 & $60 \%$ & $64 \%$ & $67 \%$ & $71 \%$ & $74 \%$ & $77 \%$ & $80 \%$ & $83 \%$ & $85 \%$ & $88 \%$ & $90 \%$ \\
\hline & 9 & $64 \%$ & $67 \%$ & $71 \%$ & $74 \%$ & $77 \%$ & $80 \%$ & $83 \%$ & $85 \%$ & $88 \%$ & $90 \%$ & $93 \%$ \\
\hline & 10 & $67 \%$ & $71 \%$ & $74 \%$ & $77 \%$ & $80 \%$ & $83 \%$ & $85 \%$ & $88 \%$ & $90 \%$ & $93 \%$ & $95 \%$ \\
\hline
\end{tabular}

Each row correspond to a given investment by your peer, each column corresponds to a given investment by yourself. The probability of success of the project for a given combination of investment by you and your peer is shown at the intersection of the corresponding row and column.

Your payment is calculated as follows:

- If project $\mathrm{K}$ is successful, then you receive $24 \mathrm{ECU}$ and have to pay your investment. If project $\mathrm{K}$ is NOT successful, then you get $0 \mathrm{ECU}$ and still have to pay your investment.

- If project $\mathrm{K}$ is successful, then your peer receives $16 \mathrm{ECU}$ and has to pay their investment. If project $\mathrm{K}$ is NOT successful, then your peer gets $0 \mathrm{ECU}$ and still has to pay their investment.

Note that your payment in case of success is different from that for your peer!

Suppose you participate in project $K$ and your peer participates in Project G2:

If you participate in project $\mathrm{K}$ and your peer participates in project $\mathrm{G} 2$, then the probability of success of project $\mathrm{K}$ depends only on your investment. You can invest any amount between 0 and 10 ECU.

The probability of success of project $\mathrm{K}$ increases with your investment as per the following formula:

$$
\text { Probability of success }=\sqrt{\text { your investment }} / \sqrt{22}
$$

The resulting probabilities can be seen in the table below:

\begin{tabular}{|c|c|c|c|c|r|r|r|r|r|r|}
\hline \multicolumn{10}{|c|}{ Your investment } \\
\hline \hline $\mathbf{0}$ & $\mathbf{1}$ & $\mathbf{2}$ & $\mathbf{3}$ & $\mathbf{4}$ & $\mathbf{5}$ & $\mathbf{6}$ & $\mathbf{7}$ & $\mathbf{8}$ & $\mathbf{9}$ & $\mathbf{1 0}$ \\
\hline $0 \%$ & $21 \%$ & $30 \%$ & $37 \%$ & $43 \%$ & $48 \%$ & $52 \%$ & $56 \%$ & $60 \%$ & $64 \%$ & $67 \%$ \\
\hline
\end{tabular}

The column headings in the table above refers to your investment, the percentages refer to the corresponding probability of success for the project.

Your payment is calculated as follows: 
- In case of a success of project $\mathrm{K}$, you receive $24 \mathrm{ECU}$ minus your investment. Otherwise you get $0 \mathrm{ECU}$ and still have to pay your investment.

- In case of a success of project G2, your peer receives 16 ECU minus their investment. Otherwise, your peer gets nothing and still has to pay their investment. Project G2 has the same characteristics as project G1, except your peer receives 16 ECU in case of success and project G2 can only be chosen by your peer. In the same way, your peer cannot choose project G1. Your payment is independent of the success of project G2.

\section{Suppose you participate in project G1:}

If you chose project G1, then the success of project G1 depends only on your investment. You can invest any amount between 0 and $10 \mathrm{ECU}$. The probability of success of project G1 increases with your investment as per the following formula:

$$
\text { Probability of success }=\sqrt{\text { your investment }+2} / \sqrt{22}
$$

The resulting probabilities can be seen in the table below:

\begin{tabular}{|c|c|c|c|c|r|r|r|r|r|c|}
\hline \multicolumn{10}{|c|}{ Your investment } \\
\hline \hline $\mathbf{0}$ & $\mathbf{1}$ & $\mathbf{2}$ & $\mathbf{3}$ & $\mathbf{4}$ & $\mathbf{5}$ & $\mathbf{6}$ & $\mathbf{7}$ & $\mathbf{8}$ & $\mathbf{9}$ & $\mathbf{1 0}$ \\
\hline $30 \%$ & $37 \%$ & $43 \%$ & $48 \%$ & $52 \%$ & $56 \%$ & $60 \%$ & $64 \%$ & $67 \%$ & $71 \%$ & $74 \%$ \\
\hline
\end{tabular}

The column headings in the table above refers to your investment, the percentages refer to the corresponding probabilities of success for the project.

Your payment is calculated as follows:

- If project G1 is successful, you receive 24 ECU minus your investment, otherwise you get nothing and still have to pay your investment.

- The payment for your peer is independent of the success of project G1. It only depends on the success of the project selected by your peer in this period and on his investment in that project.

\section{Overview of the choices to make}

In each period you have to:

- Choose either project $\mathrm{K}$ or project G1.

- Then choose how much you want to invest (between 0 ECU and 10 ECU) to the project you selected.

In each period you will be asked:

- How likely it is that your peer chooses project G2. If you guess your peer's decision exactly you receive 5 ECU extra. If your guess is off by $x \%$ you get $5-(x / 10)$ ECU. If you guess is off by more than $50 \%$ then you get nothing from your guess.

- What investment you expect your peer to make in their selected project. If you guess the exact amount invested by your peer, you receive 5 ECU extra. If your guess is off by $x$ ECU then you get 5-x ECU. If your guess if off by more than 5 ECU then you get nothing from your guess.

Only one of the guesses (choice of project or investment) will be used to determine your earnings. 


\section{Earnings}

Your earnings will be the sum of

1. 10 ECU for participating,

2. PLUS 24 ECU or 0 ECU depending on if your chosen project in the period chosen for payment was successful or not,

3. MINUS your investment in your chosen project in the period chosen for payment,

4. PLUS a payment up to $5 \mathrm{ECU}$ for your guess in either the choice of project or the investment of your peer in their chosen project in the period chosen for payment.

5. PLUS a payment for a few additional decisions unrelated to the main part of the experiment.

\section{Notes}

- You can invest any numbers of ECU between 0 and 10 ECU with a precision up to the second decimal place. You will be given the opportunity to calculate the resulting probabilities of success for your chosen project on your computer.

- You will be provided with information about your project choices and the choices of your peer, and whether your chosen project was successful, for each past period in a given round.

- Reminder: Your payment for a given period is the value of the project you selected in that period (either $24 \mathrm{ECU}$ in case of success or $0 \mathrm{ECU}$ in case of failure) MINUS your investment in that project.

\section{B.2. Additional tasks and questionnaire}

\section{Aversion to risk and strategic uncertainty}

The two following tasks are taken from Heinemann et al. (2009). In the risk task, subjects were presented with ten lottery comparisons, whereby lottery A offered a safe payoff ranging from 1 to $10 \mathrm{ECU}$ and lottery B offered $0 \mathrm{ECU}$ with probability half and $10 \mathrm{ECU}$ with probability half. Measure $r a$ of risk aversion is the number of times the subjects chose the safe payoff (lottery A), rather than lottery B. This does not impose the restriction that if A was chosen when it gave $x$ ECU then it ought to be chosen when it gives any safe payoff $y>x$. Imposing such a restriction would make the choices expressed by 28 participants invalid.

In the strategic uncertainty task, subjects were put in groups of four and presented with ten lottery comparisons, whereby lottery A offered a safe payoff ranging from 1 to 10 ECU and lottery B offered 0 ECU if less than 3 group members chose lottery B as well in that choice instance, and 10 ECU if 3 or all group members chose lottery B in that choice instance. Measure $s u$ of risk aversion is the number of times the subjects chose the safe payoff (lottery A), rather than lottery B. Imposing the restriction that if $\mathrm{A}$ was chosen when it gave $x$ ECU then it ought to be chosen when it gives any safe payoff $y>x$ would make the choices expressed by 21 participants invalid.

\section{Social value orientation}

Subjects were asked to allocate payoff between themselves and another participants in the session, while they did not know what role (Decider or Recipient) they would be assigned to. There were 6 vectors of allocations to choose from, each with 9 elements, whereby subjects were asked, for each vector, which of the 9 possible allocation they preferred. Vectors are shown in Table B.13. 


\begin{tabular}{|c|c|c|c|c|c|c|c|c|c|c|}
\hline & & 1 & 2 & 3 & 4 & 5 & 6 & 7 & 8 & 9 \\
\hline \multirow[t]{2}{*}{1} & Payoff for me & 5.0 & 5.4 & 5.9 & 6.3 & 6.8 & 7.2 & 7.6 & 8.1 & 8.5 \\
\hline & Payoff for other & 10.0 & 8.9 & 7.9 & 6.8 & 5.8 & 4.7 & 3.6 & 2.6 & 1.5 \\
\hline \multirow[t]{2}{*}{2} & Payoff for me & 8.5 & 8.7 & 8.9 & 9.1 & 9.3 & 9.4 & 9.6 & 9.8 & 10.0 \\
\hline & Payoff for other & 1.5 & 1.9 & 2.4 & 2.8 & 3.3 & 3.7 & 4.1 & 4.6 & 5.0 \\
\hline \multirow[t]{2}{*}{3} & Payoff for me & 5.0 & 5.4 & 5.9 & 6.3 & 6.8 & 7.2 & 7.6 & 8.1 & 8.5 \\
\hline & Payoff for other & 10.0 & 9.8 & 9.6 & 9.4 & 9.3 & 9.1 & 8.9 & 8.7 & 8.5 \\
\hline \multirow[t]{2}{*}{4} & Payoff for me & 8.5 & 8.5 & 8.5 & 8.5 & 8.5 & 8.5 & 8.5 & 8.5 & 8.5 \\
\hline & Payoff for other & 8.5 & 7.6 & 6.8 & 5.9 & 5.0 & 4.1 & 3.3 & 2.4 & 1.5 \\
\hline \multirow[t]{2}{*}{5} & Payoff for me & 10.0 & 9.4 & 8.8 & 8.1 & 7.5 & 6.9 & 6.3 & 5.6 & 5.0 \\
\hline & Payoff for other & 5.0 & 5.6 & 6.3 & 6.9 & 7.5 & 8.1 & 8.8 & 9.4 & 10.0 \\
\hline \multirow[t]{2}{*}{6} & Payoff for me & 10.0 & 9.8 & 9.6 & 9.4 & 9.3 & 9.1 & 8.9 & 8.7 & 8.5 \\
\hline & Payoff for other & 5.0 & 5.4 & 5.9 & 6.3 & 6.8 & 7.2 & 7.6 & 8.1 & 8.5 \\
\hline
\end{tabular}

Choices made by the subjects were summarized in one measure as per Murphy et al. (2011) with

$$
s v o=\arctan \left(\frac{\text { mean }(\text { payoff for other }-5)}{\text { mean }(\text { payoff for me }-5)}\right)
$$

Higher svo indicates higher concern for others, up to perfect altruism (maximization of the payoff of the other). Lower svo indicates less altruistic behavior, up to perfectly competitive behavior (maximizing the difference between one's payoff and the one by the other). svo may takes values between -0.28 and 1.07 given the range of choices provided.

\section{Questionnaires on trustfulness}

The following questions are taken from the fairness, trust and helpfulness questions in the General Social Survey of the National Opinion Research Center at the University of Chicago.

1. Do you agree with the following three statements:

(a) In general, one can trust people.

(b) Nowadays, one can't rely on anybody.

(c) When dealing with strangers, it's better to be cautious before trusting them.

The possible answers on a four point rating scale are "disagree strongly", "disagree somewhat", "agree somewhat", or "agree strongly".

2. Would you say that most people...

(a) would try to take advantage of you if given the opportunity...

(b) or would try to be fair to you?

3. Would you say that most people...

(a) try to be helpful...

(b) or follow only their own interests?

We computed an index of trustfulness from the answer to those questions, using a single-factor measurement model whereby answers to questions $1 \mathrm{a}, 1 \mathrm{~b}$ and $1 \mathrm{c}$ are modeled as ordered logit and answers to questions 2 and 3 are modeled as logit. The index ranged from -3.49 (least trustful) to 3.63 (most trustful). 


\section{References}

Anderson, T. AND C. HsiaO (1981): "Estimation of Dynamic Models with Error components," Journal of the American Statistical Association, 76, 598-606.

GuAN, W. (2003): "From the help desk: Bootstrapped standard errors," The Stata Journal, 3, 7180.

Heinemann, F., R. NAGel, AND P. OCKenfels (2009): "Measuring strategic uncertainty in coordination games," The Review of Economic Studies, 76, 181-221.

MuRPhy, R., K. ACKERMANN, AND M. HANDGRAAF (2011): "Measuring social value orientation," Judgment and Decision Making, 6, 771-781.

SEMYKina, A. AND J. M. WoOldRIDGE (2010): "Estimating panel data models in the presence of endogeneity and selection," Journal of Econometrics, 157, 375-380.

- (2013): "Estimation of dynamic panel data models with sample selection," Journal of Applied Econometrics, 28, 47-61.

WoOLDRIDGE, J. M. (1995): "Selection correction for panel data models under conditional mean independence assumptions," Journal of Econometrics, 68, 115-132. 